$$
\begin{gathered}
\text { جارجوب مديريت محيط زيستى و اجتماعى بروزه ارتقاى بِلان كذارى و ظرفيت } \\
\text { بـ افغانستان برشنا شركت }
\end{gathered}
$$


فهزست مطالب

خلاصه (جرائيوى

1 1.1 2.1 3.1 4.1 5.1 تاثيرات بالقوه محيط زيسنى و اجتماعى

2. 1.2 2.2

$$
3 .
$$

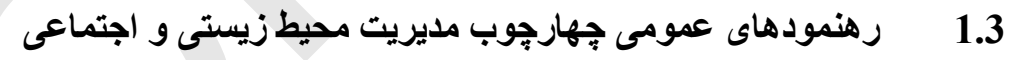
2.3

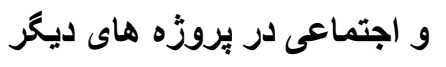

3.3

ترتيات ادارى: شرايط، بروسه هاو مسوليت ها براى ارزيابى مسايل ايمنى و كاهش تاثيرات 3.6 3.5 3.7 آموزش هاى عمده محيط زيستى و اجتماعى تحت جز اول 3.8 3.8 نشر معلومات 3.9 
لست ضميمه ها

21

22

24

29

35

41

44

51

56

116

123

124

131
ضميه 1: مشخصات بروزْه هاى فرعى فاقد شرايط لازم

ضميمه 2: طرزالعمل هاى مشاهده آثار احتمالى

ضميمه 3: فورمه ارزيابى محيط زيستى و اجتماعى

ضميمه 4: شرايط عمومى براى يك ارزيابى كامل تاثيرات اجتماعى

ضميمه 5: شرايط عمومى براى يك ارزيابى كامل تاثيرات محيط زيستى

ضميمه 6: بِلان تفصيلى مليريت محيط زيستى و اجتماعى

ضميمه 7: طرزالعمل ارزيابى تاثيرات محيط زيستى در اداره ملى حفاظت از محيطزيست ضميمه8: رهنمود هاى محيط زيستى براى قرارداديان ضميمه 9: بֶلان نظارتى محيط زيستى

ضميمه 10: جهارجوب استملاك زمين و اسكان مجدد ضميمه11: (الف) اجزاى يّلان اسكان مجدد

ضميمه : 11 (ب): لايحه وظايف عمومى براى نهاد خارجى نظارت بر تطبيق بِلان اسكان مجدد ضميمه 12: فورم نمونوى ثبت شكايات ضميمه 13: فورمه نمونوى كذارش دهى براى كارمندان ايمنى ضميمه 14: خلاصه جريان مشوره ها در كابل درمورد جهارجوب مديريت محيطزيستى و اجتماعى ضميمه 15: رهنماى محيط زيستى، صحت و ايمنى براى انتقال و توزيع انرزى برق 


\section{خلاصه (جرايوى}

ب بس منظر بروزْه

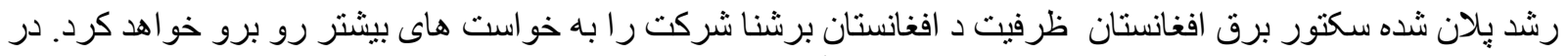

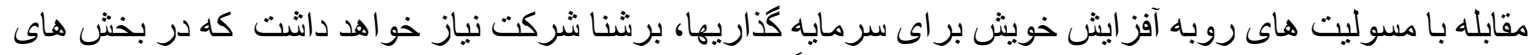

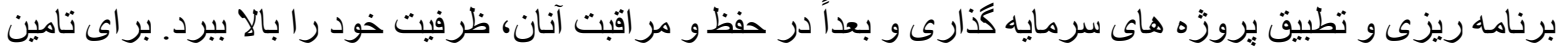

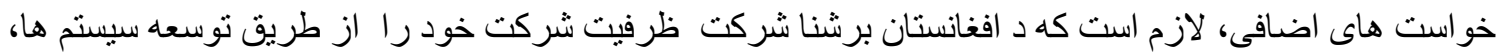

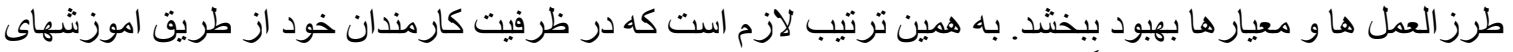

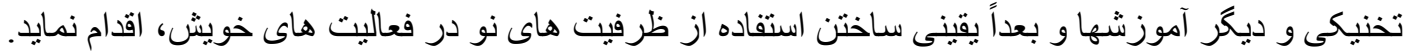

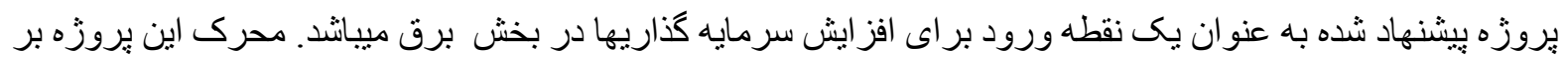

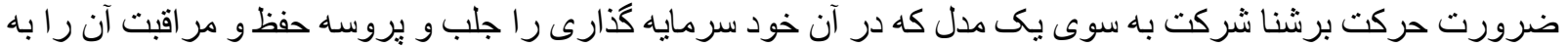

بيش بيرد، بنا يافته است.

\section{هدف بְروزْه}

بهاود يايدار ظرفيت برشنا شركت تا بتو اند سرمايه كذارى را برنامه ريزى و سيستم توزيع برق را حفظ و مر اقبت نمايد.

شرح بِروزْه

بروزه شامل دو جز ميكردد: (1) ظرفيت سازى كارمندان د افغانستان برشنا شركت و(2) و توسعه مركز اموزشى

مدت بِروزْه

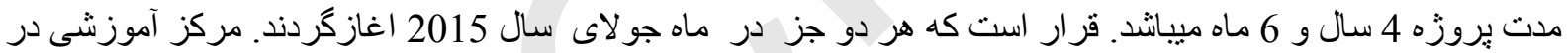

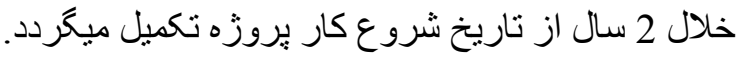

تاثيرات محيط زيستى و اجتماعى بالقوه اجزاى بروزْه

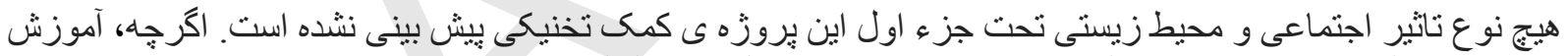

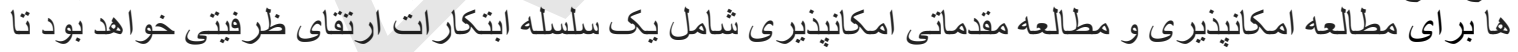

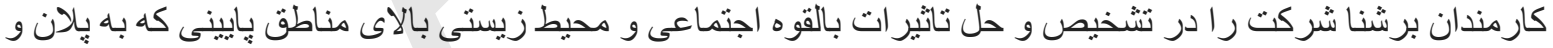

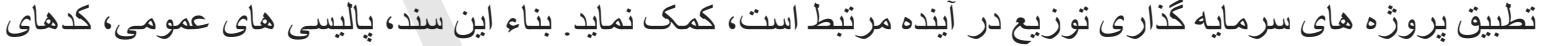

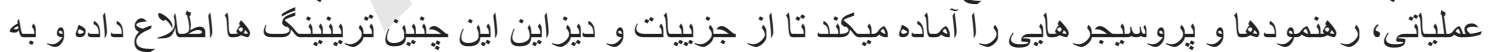

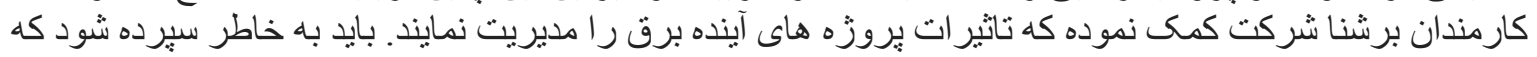

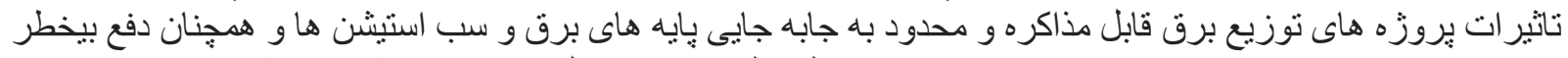

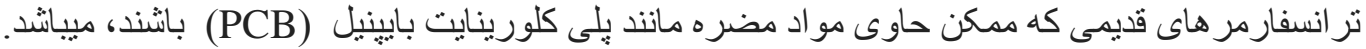

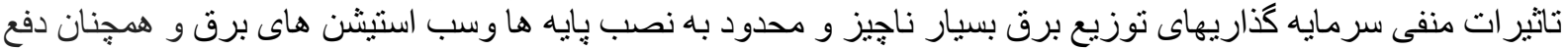

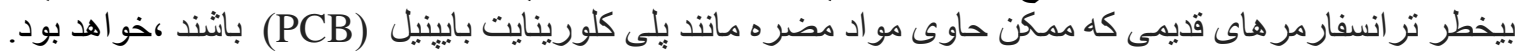

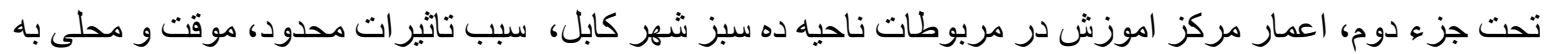

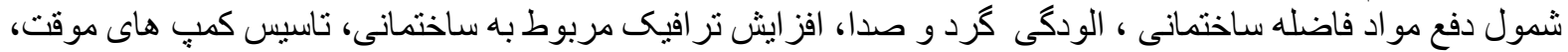

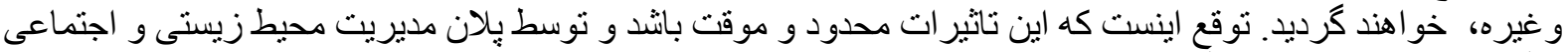

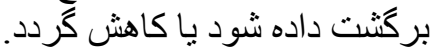


مطمئن كليه اقدامات كاهش ناثثير ات محيط زيستى و اجتماعى مندر ج بِلان هاى مديريتى محيط زيستى و اجتماعى، نظارت نمايند.

\section{ميكانيزم حل شكايات}

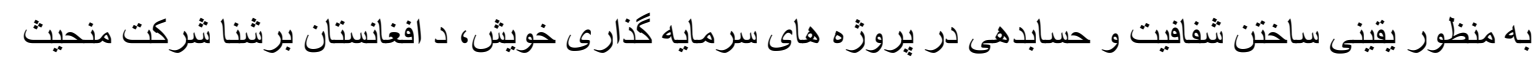

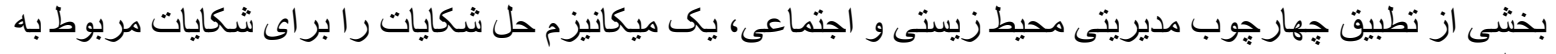

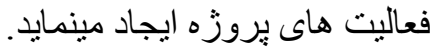

بخش عملياتى برشنا شركت و تيم ايمنى محيط زيستى و اجتماعى نقش مهر رات را دارند كه اطمينان حاصل نمايند كه مردم

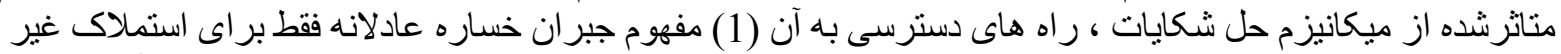

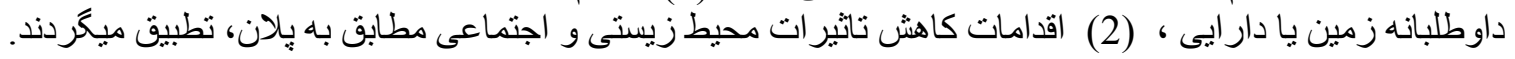




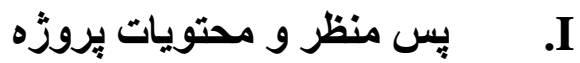

\section{I}

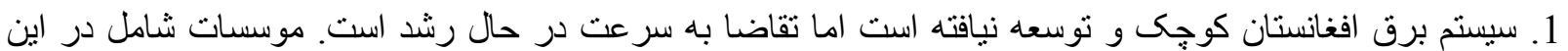

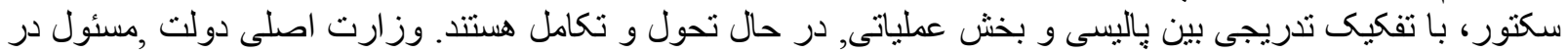

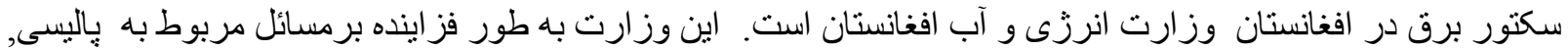

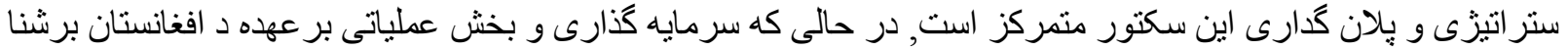

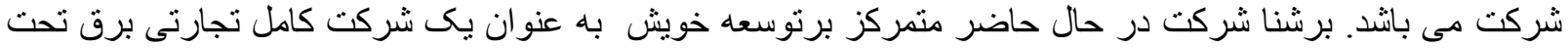

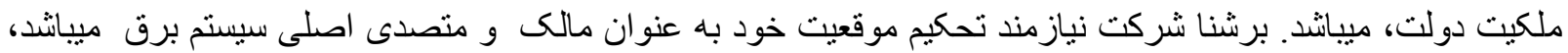

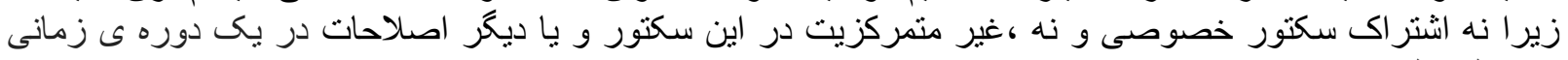
متوسط منظر و اقع بينانه اى ندارد.

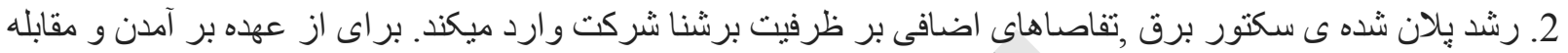

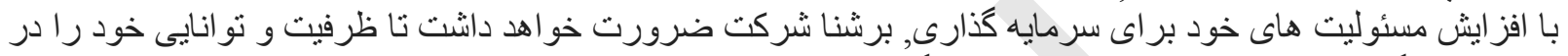

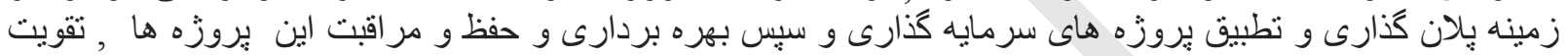

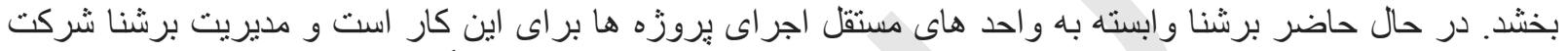

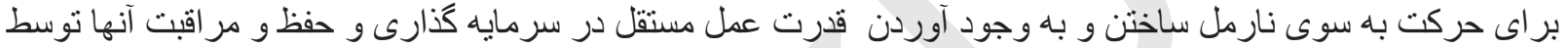

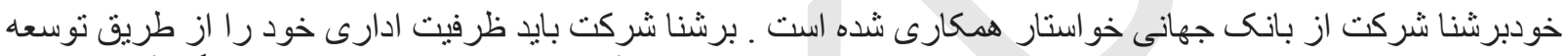

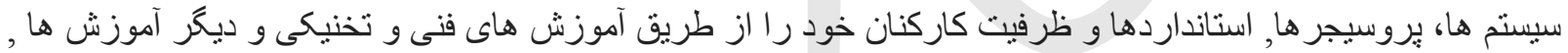

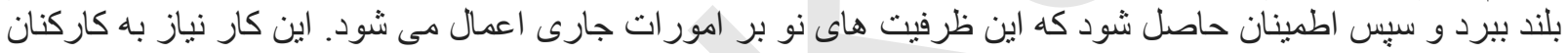

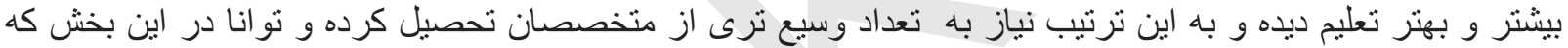

شامل زنان هم بايد باشند, دارد. دون.

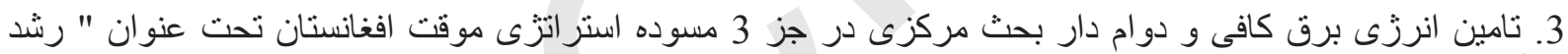

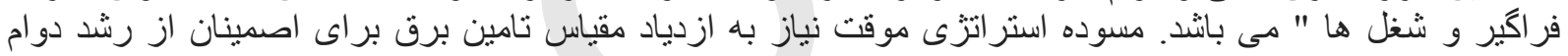

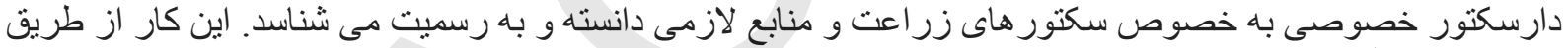

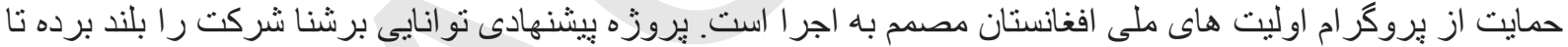

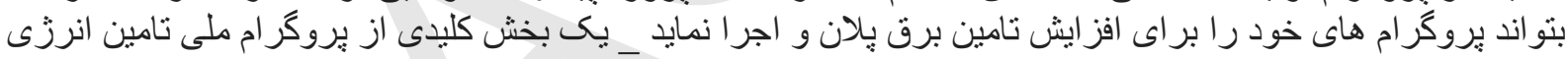

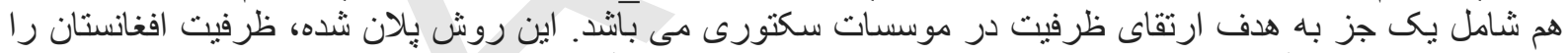

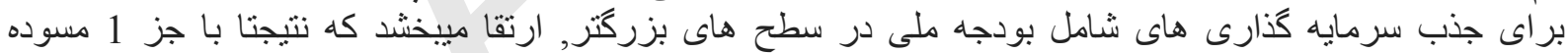

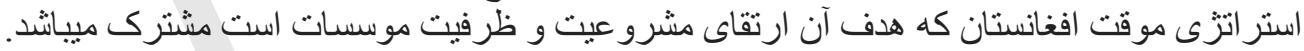

\section{I}

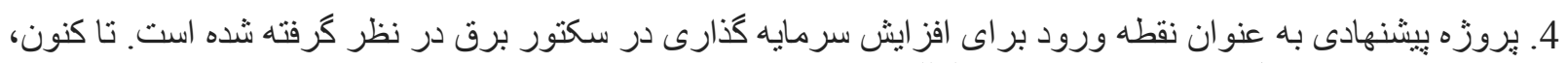

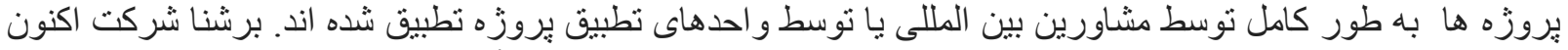

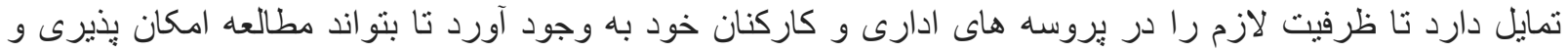

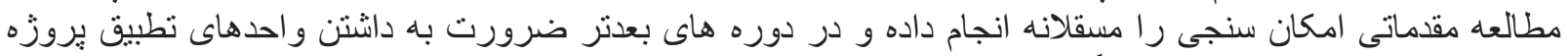

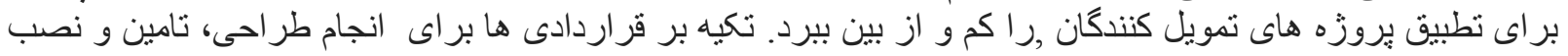

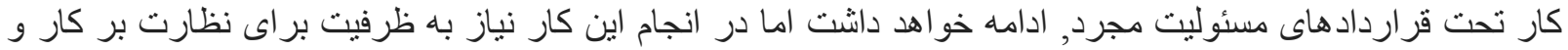
مهمتر از همه مديريت قرارداد مادها ميباشند.

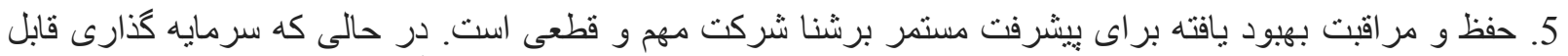

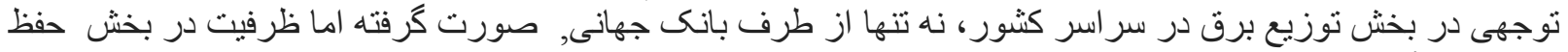
و مر اقبت آنجنان بهجود نيافته است. حفظ و مر اقبت سيستم يكى از تو انايى هاى عمده و مهم بر ایى يك شركت محسوب 


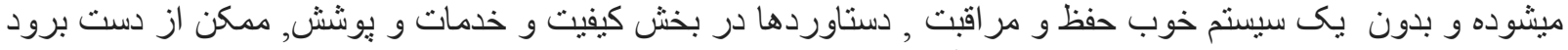

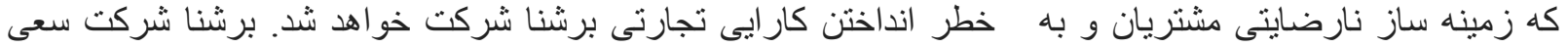

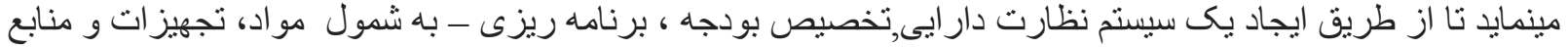

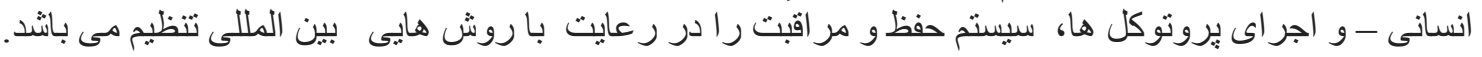

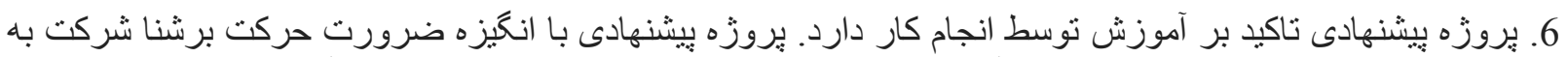

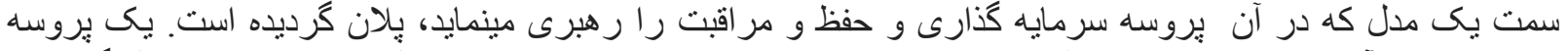

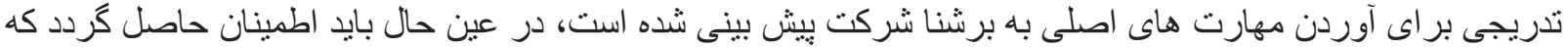

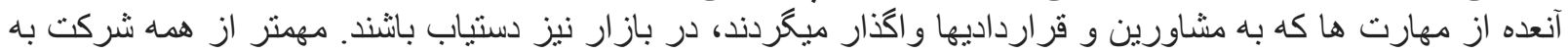

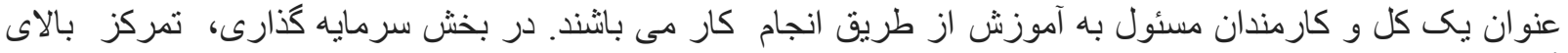

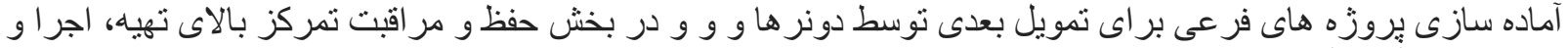

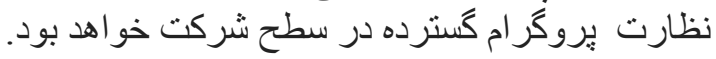

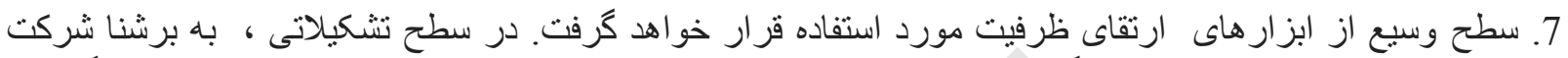

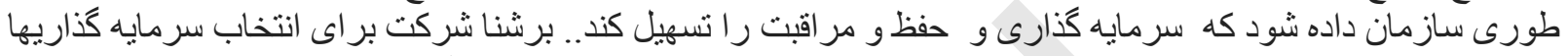

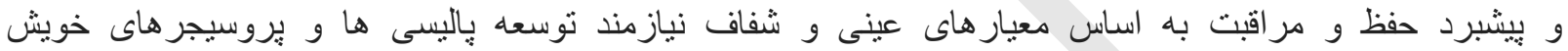

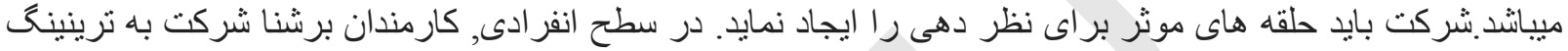

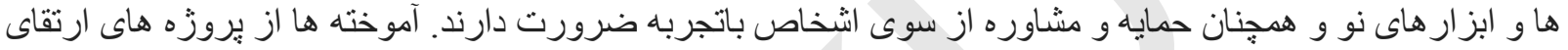

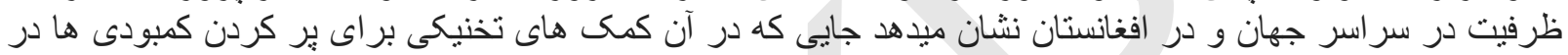

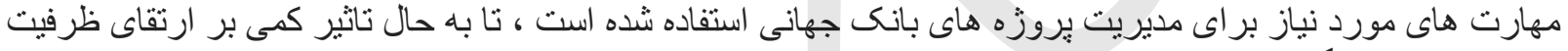

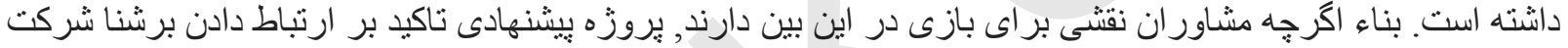

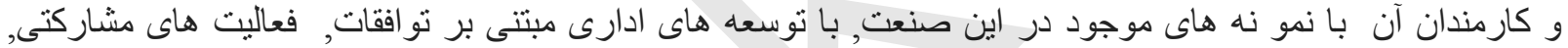

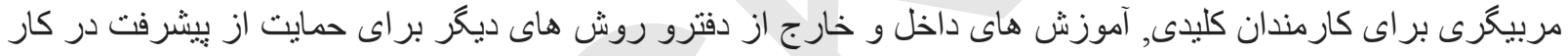
روزانه خود, دارند.

\section{I}

8. هدف توسعه ایى بروزه بهجود ظرفيت برشنا شركت در بِلان سرمايه كذارى و مر اقبت سيستم توزيع برق مى باشد. 9. نتايج كليدى ذيل جستجو خو اهد شد:

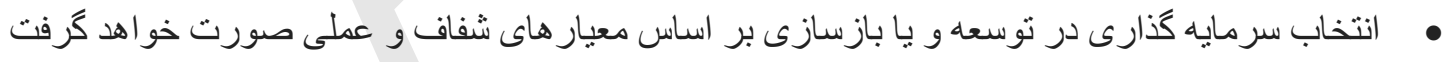

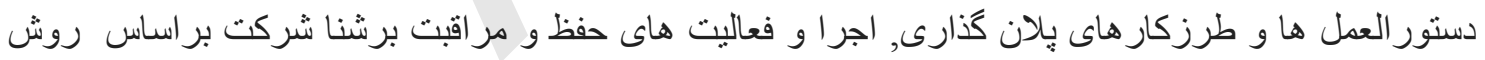

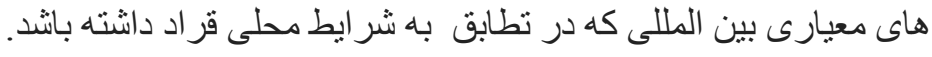

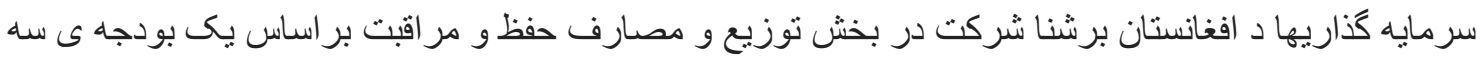
ساله تنظيم ميكرد دايه دارد ديبارتمنت هاو اثخاص كليدى حسابده يّان كذارى هار تطبيق و هم جنان اجرا ع حفظو مر اقبت خو اهند بود. 4. I يروزْه شامل دو جزء ذيل مى باثند: 10. جزء اول: ارتقاى ظرفبت كارمندان برشنا شركت: اين جزء بِروزه از ارتقاى ظرفيت كارمندان برشنا شركت حمايت خو اهد كرد كه شامل:

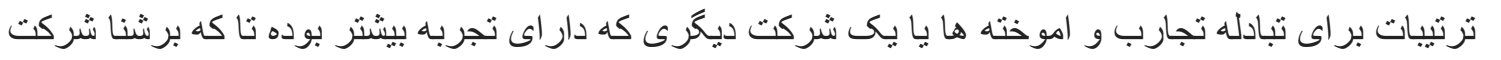

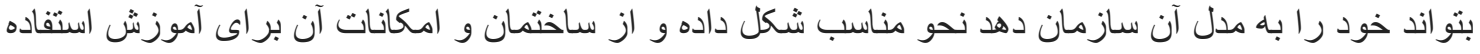


نمايد. جنين موسسه اى بايد به طور مطلوب دار ایى عملكرد عالى, موقعيت نزديك و و كارمندان آن دار ایى تجربه

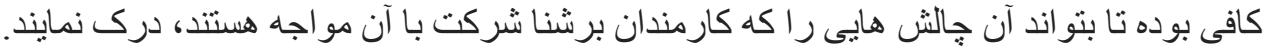

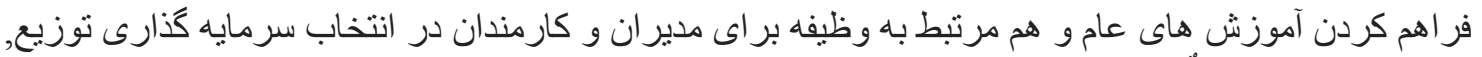

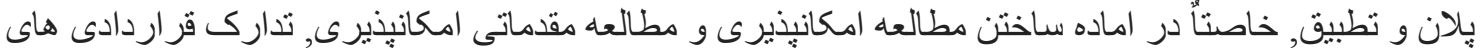

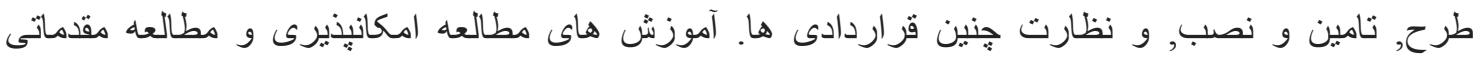

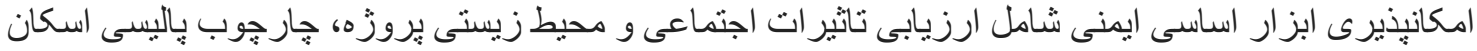

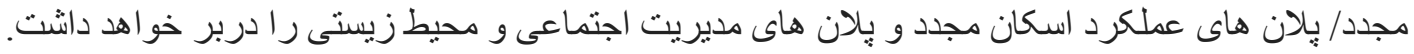

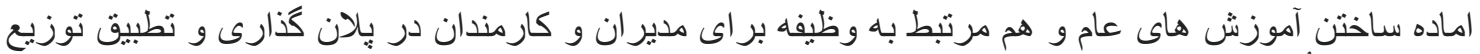

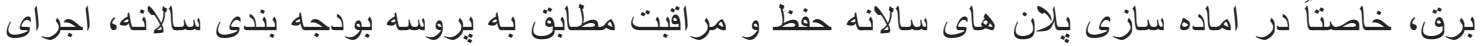

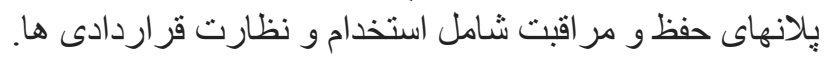

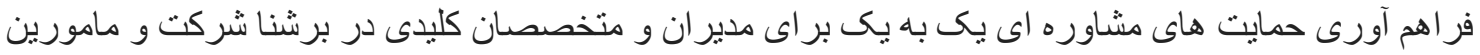
حفظ و مر اقبت

قادرساختن برشنا شركت جرت تامين يك مسير شغلى به كارمندان اناث متخصص در برشنا شركت، شامل

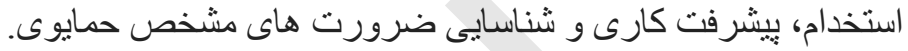

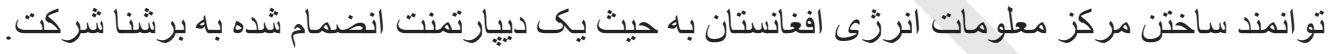
11. جزء دوم: /يجاد مركز آموزشى ـ اين جزء از ايجاد يكى مركز آموزشى در برشنا شركت حمايت ميكند كه شامل:

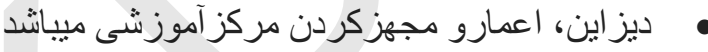

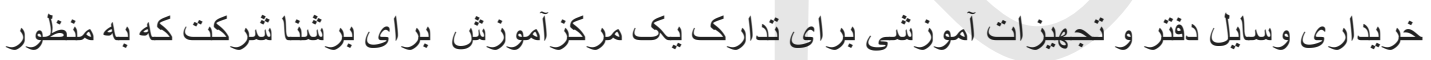
بركذارى ترينينى ها مورد استفاده قر ار ميكيرد.

5. I

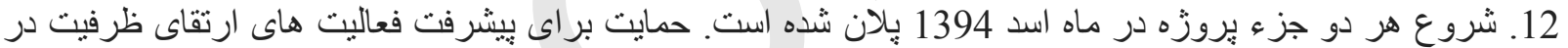

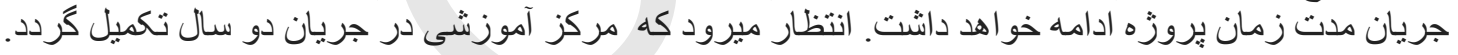

6. I

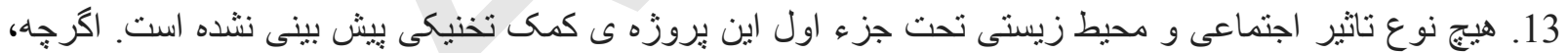

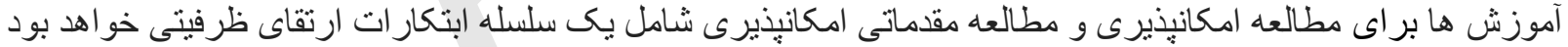

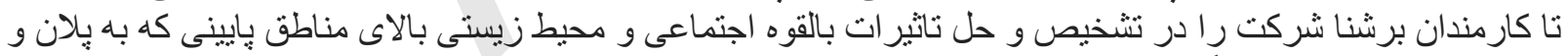

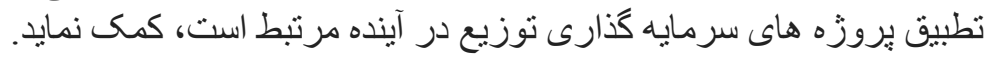

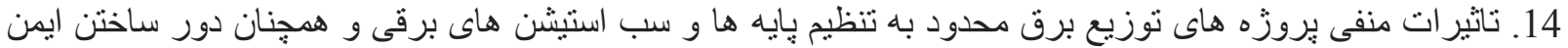

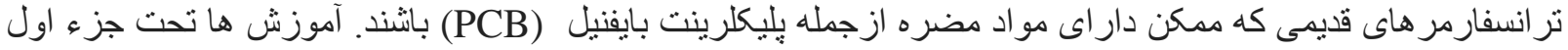

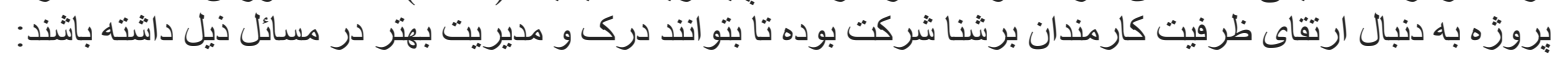

a. تنظيم لين هاى برق: تتظيم لين هاى برق تحت بروز هابه هاى سرمايه كذارى انتخاب شود كه بناء دريافت كننده

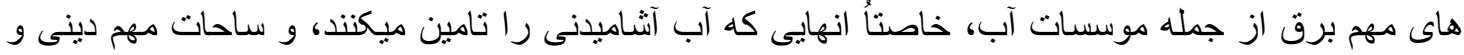

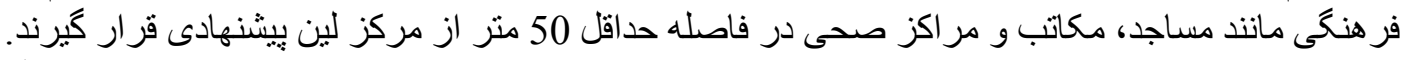

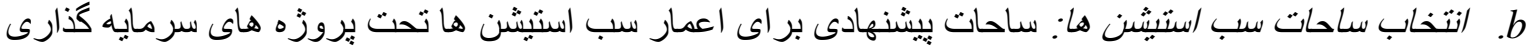

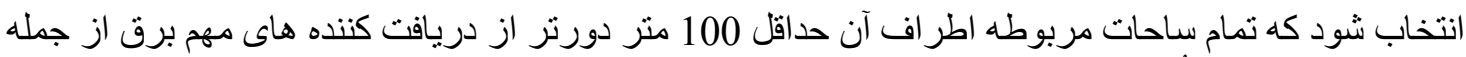

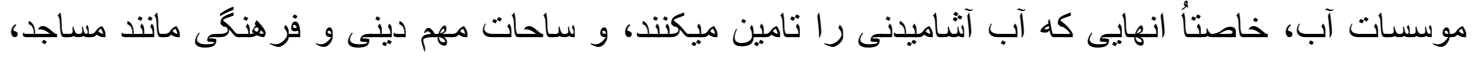
مكاتب و مر اكز صحى باثند. 


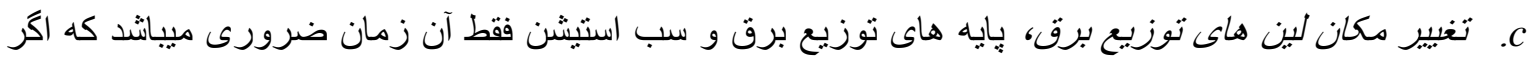

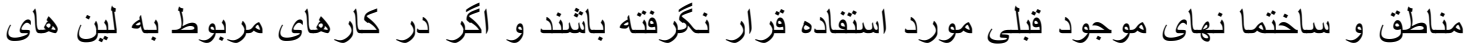

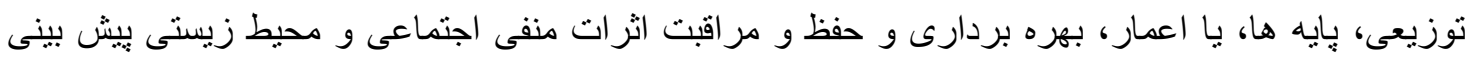
كردد.

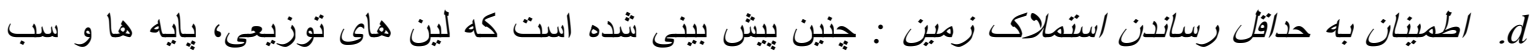

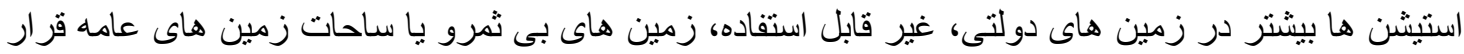

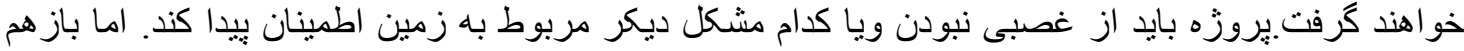

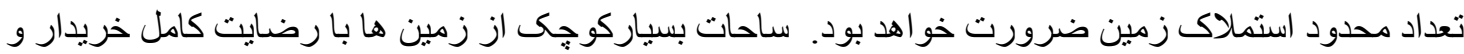

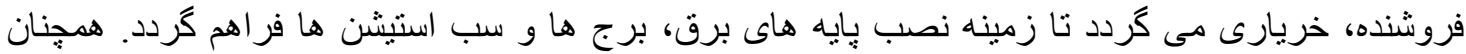

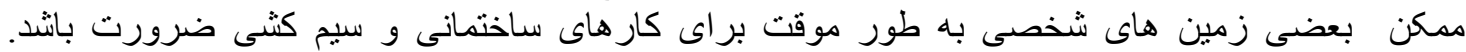

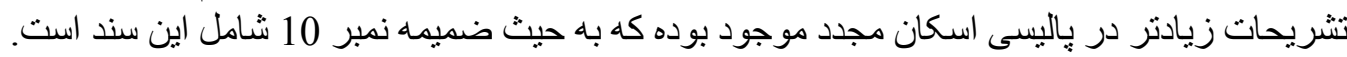

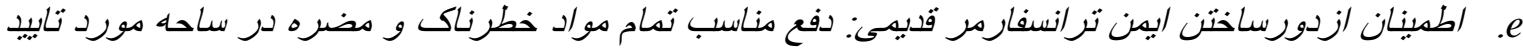
دولت.

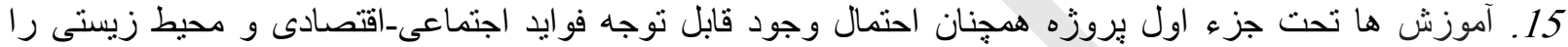

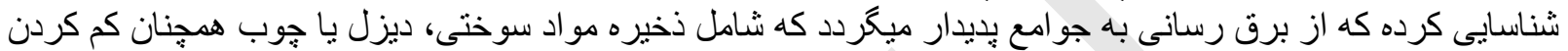

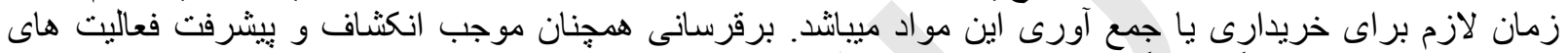

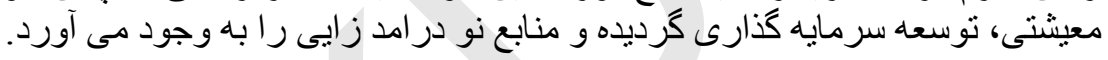

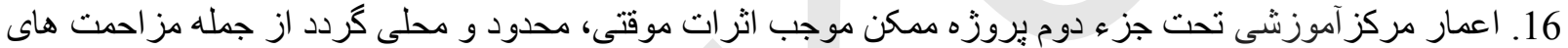

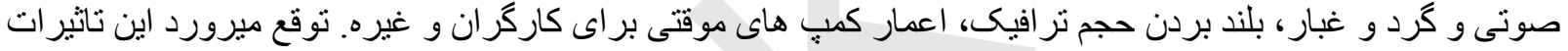

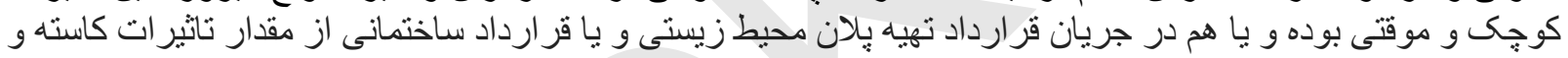

از بين برده شوند.

2. - 2 جهارجوب باليسى، حقوقى و مقرراتى

1.2 پاليسى هاى عملياتى بانك جهانى كه در بروزُه ارتقاى ظرفيت و پلان كذارى برشنا شركت متاثر ميكردند:

\begin{tabular}{|c|c|c|}
\hline خير & بله & باليسى حفاظتى كه توسط اين بروزه در نظر كرفته شده \\
\hline [ ] & {$[\mathrm{X}]$} & ارزيابى محيط زيستى (OP/BP 4.01) \\
\hline$[\mathrm{X}]$ & [ ] & محل سكونت طبيعى (OP/BP 4.04) \\
\hline$[\mathrm{X}]$ & [ ] & مديريت آفت ها(OP 4.09) \\
\hline$[\mathrm{X}]$ & [ ] ] & منابع فزيكى فرهنكى (OP/BP 4.11) \\
\hline [ ] & {$[\mathrm{X}]$} & اسكان مجدد اجبارى (OP/BP 4.12) \\
\hline$[\mathrm{X}]$ & [ ] & مردم بومى (OP/BP 4.10) \\
\hline$[\mathrm{X}]$ & [ ] ] & جنحلات (OP/BP 4.36) \\
\hline$[\mathrm{X}]$ & [ ] & ايمنى بندها (OP/BP 4.37) \\
\hline$[\mathrm{X}]$ & [ ] & بروزه ها در مناطق نا آرام (OP/BP 7.60) \\
\hline [ ] & [ ] ] & بروزه ها در راه هاى آبى بين المللى (OP/BP 7.50) \\
\hline
\end{tabular}

17. ارزيابى محيط زيستى (EA OP/BP 4.01): ارزيابى محيط زيستى به اين دليل در نشر كرفته شده كه ممكن موارد ذيل بعضى تاثير ات منفى به همر اه داشته باثند:

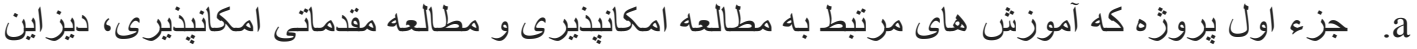

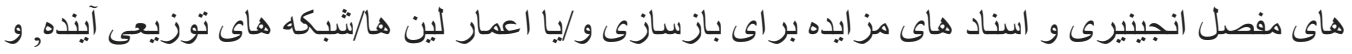




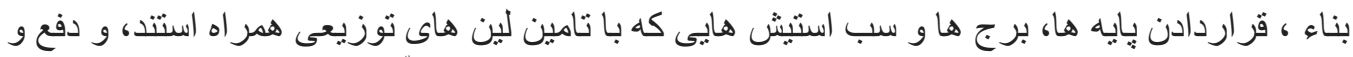

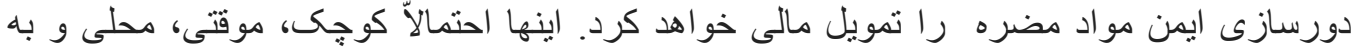

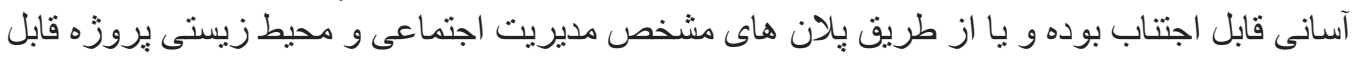
كم ساختن ميباشند.

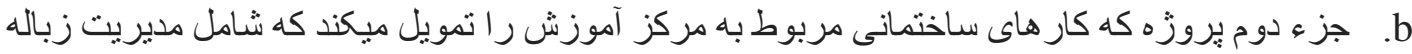

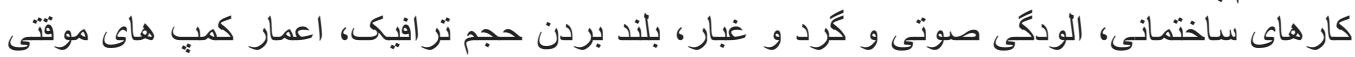

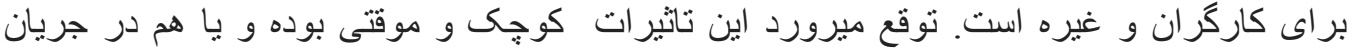

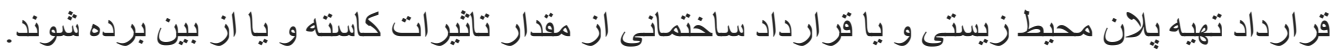

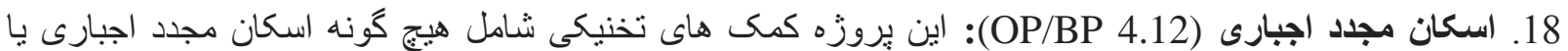

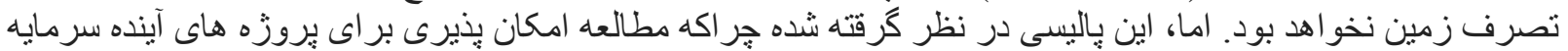

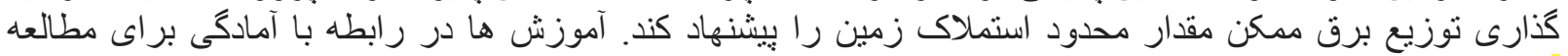

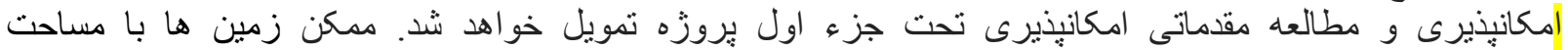

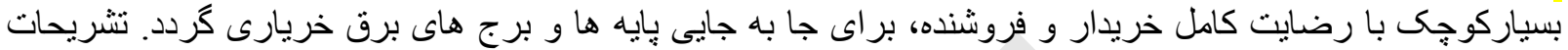

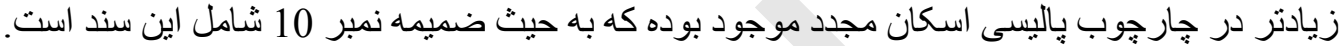

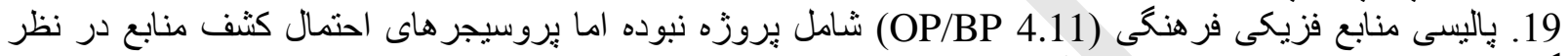

كرفته ميشود . ( ضميمه نمبر 2 رابع فطالعه نماييد)

\section{2 جهارجوب حقوقى و مقرراتى افغاتستان}

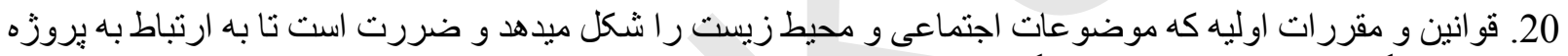

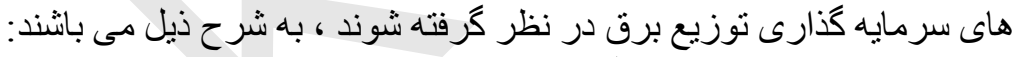

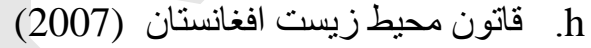

i

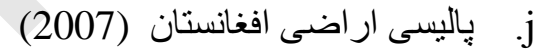

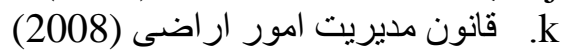

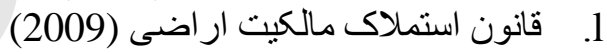

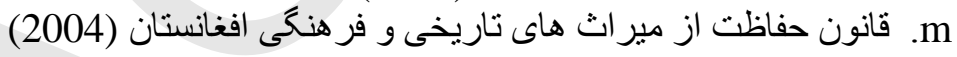

21. قانون محيط زيست اففانستان، در سال 2007 تصويب شده و اكثر جنبه هاى مديريت منابع طبيعى را شأشامل است.

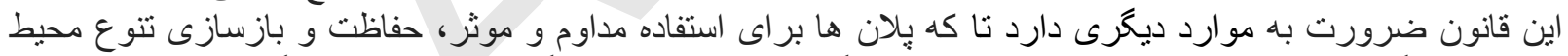

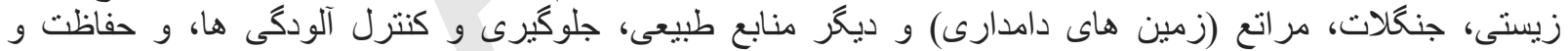

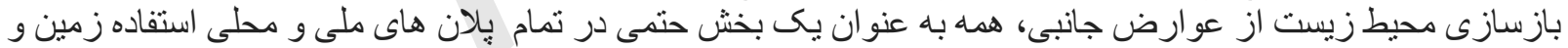

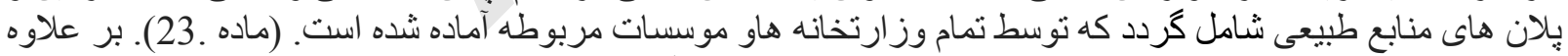

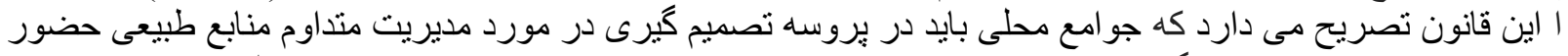

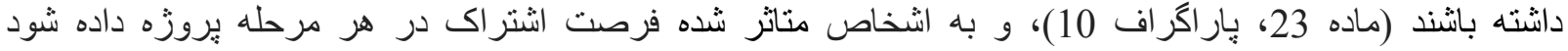

22. اداره ملى حفاظت از محيط زيست (NEPA): اداره ملى حفاظت از محيط زيست در سال 2005 ناسيس شد. اين اين

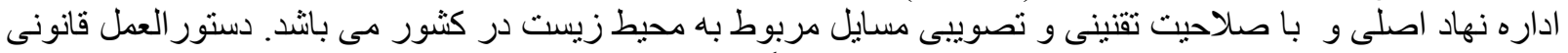

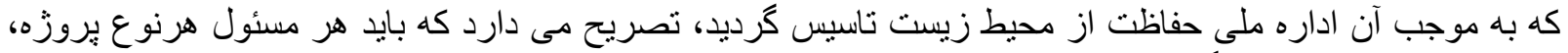

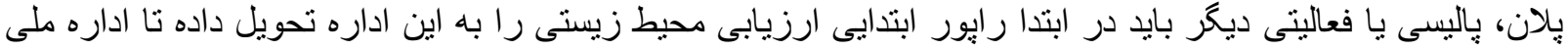

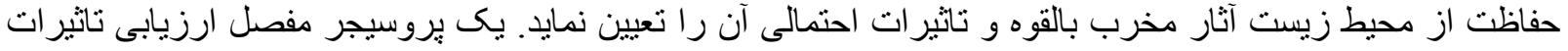

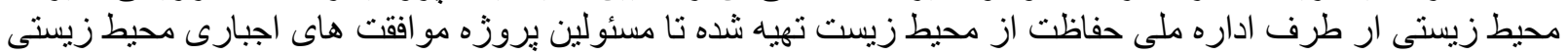

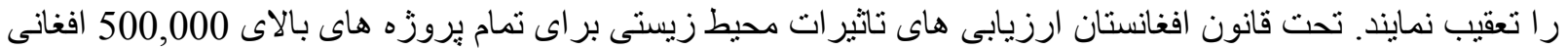




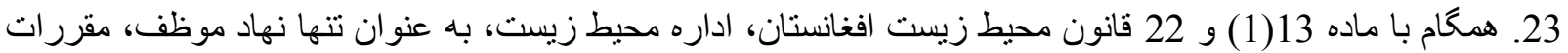

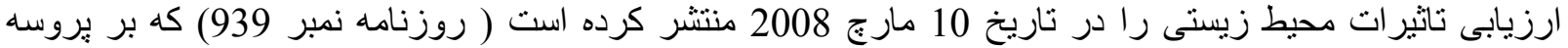

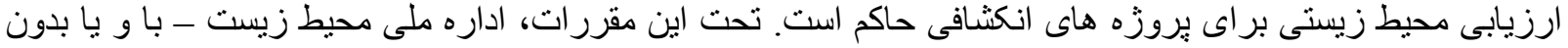

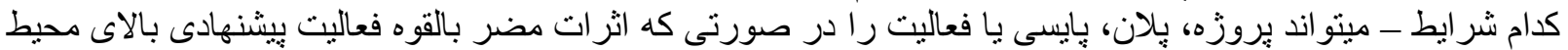

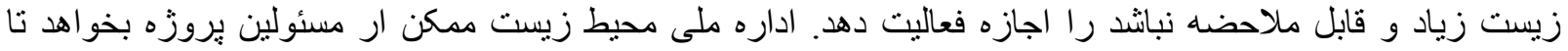

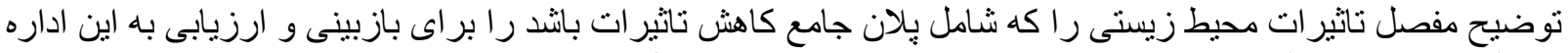
تحويل نمايند. اداره ملى محيط زيست همجنان موضف به تصو تصويب مسائل اجتماعى نيز ميباشند.

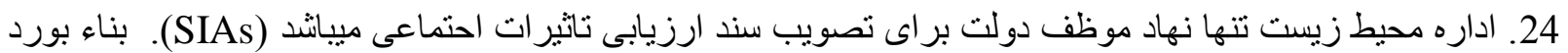

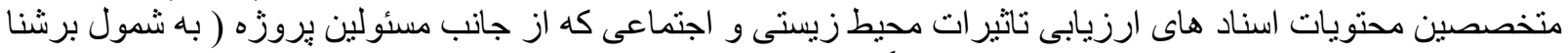

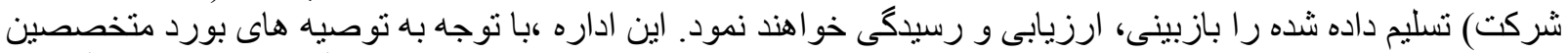

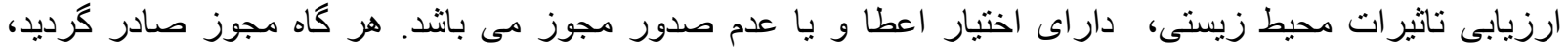

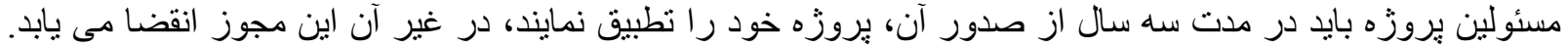

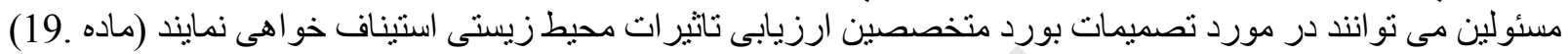

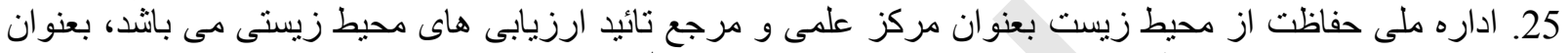

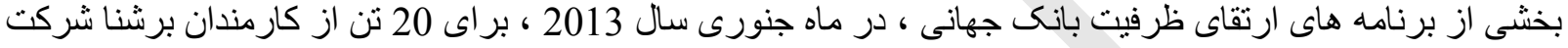

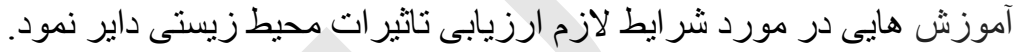

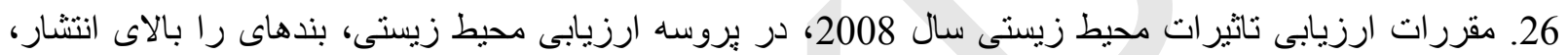

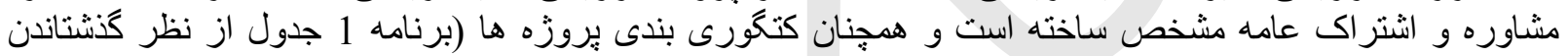

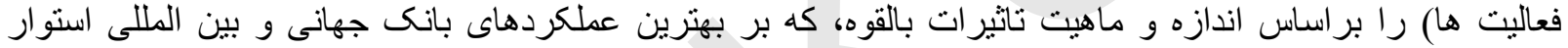
ميباشند، تعيين نموده است.

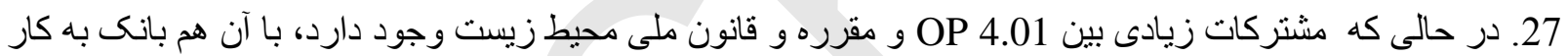

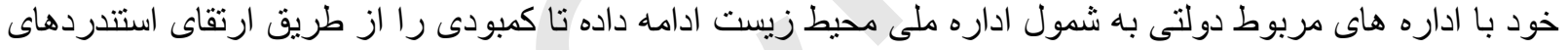
بين المللى محيط زيست و تمرين و تقويت تطبيق و اجبار ى ساختن جارجوب مقرره محيط زيستى ، مرفوع بسازد.

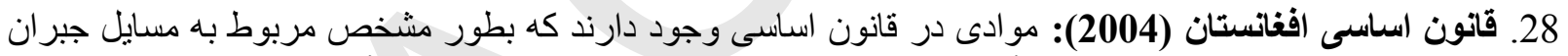

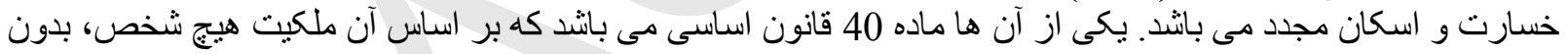

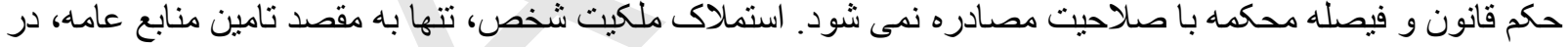

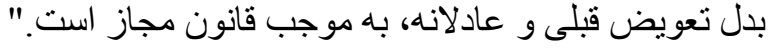

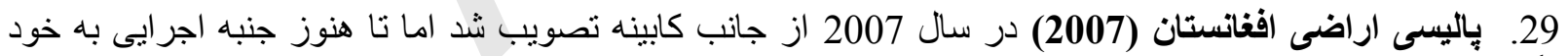

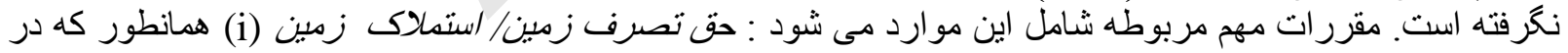

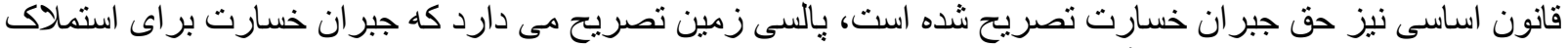

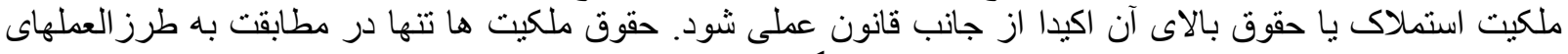

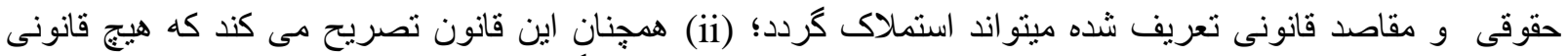

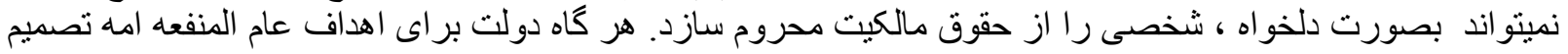

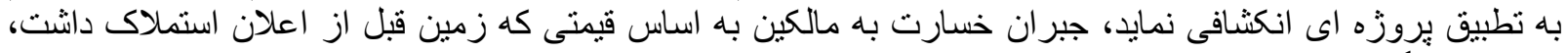

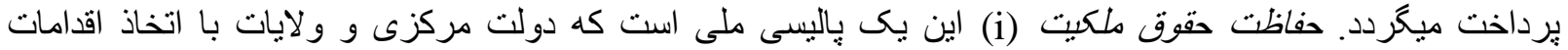

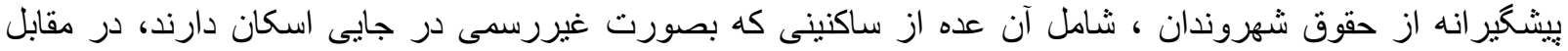

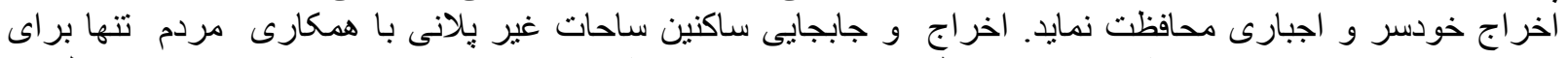

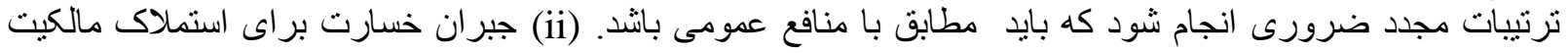

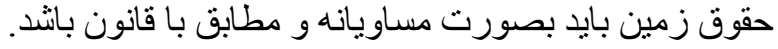


30. قانون امور زميندارى ( 2008) هدف قانون مديريت ار اضى اين است تا يك سيستم مديريت قانونى ار اضىى، منسجم

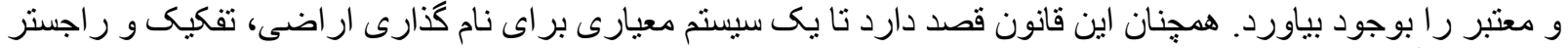

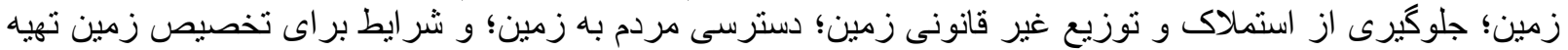

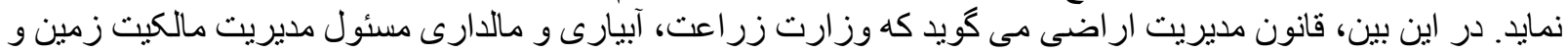

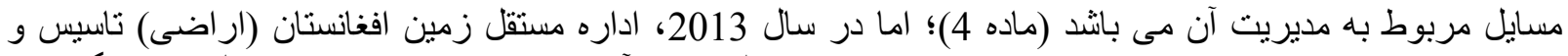

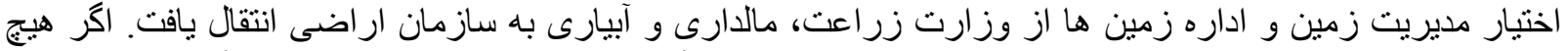

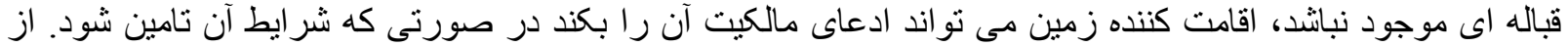

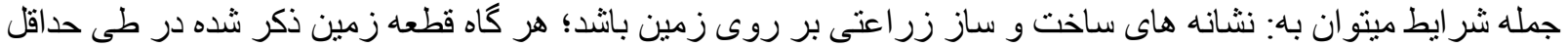

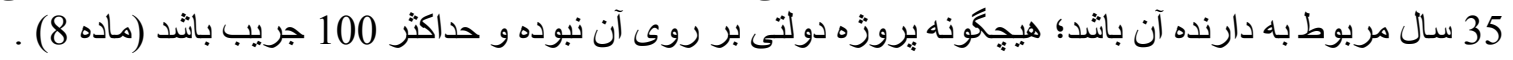

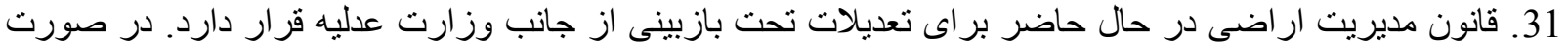
تصويب، تعديلات مينو اند بِيامدهاى در قسمت جارجوب جبران خسارت در شر ايط دعوى هاى مشرع معتبر دانته باتثد.

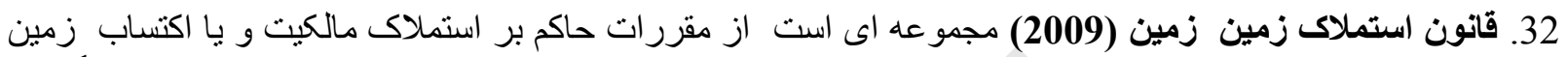

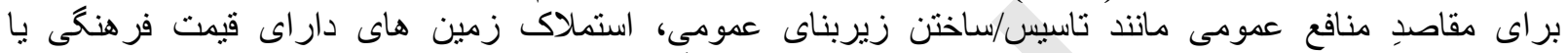

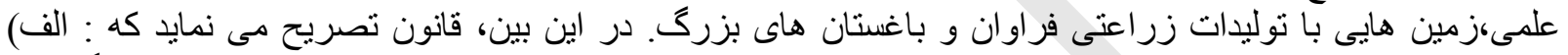

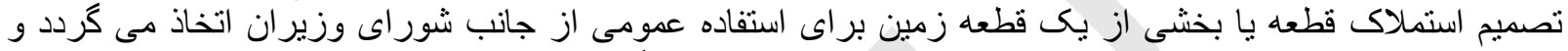

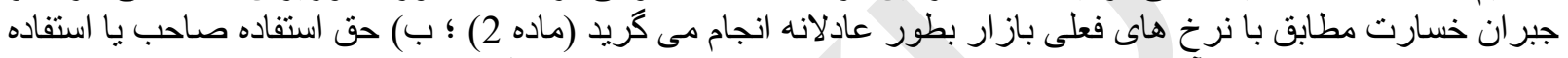

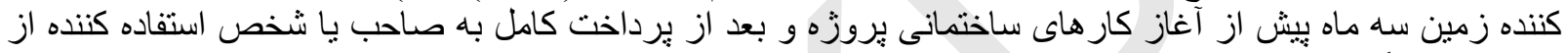

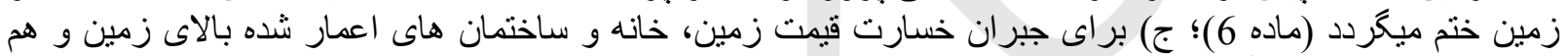

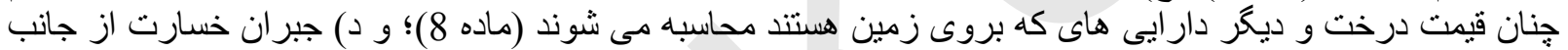
شور اي وزير ان تعيين مى شود د. دئ.

33. شر ايط انتخاب مستحقين جبران خسارت مانند صاحبان زمين، اقامت كننده هاى زمين، مستاجرين زمين، كرين كرايه

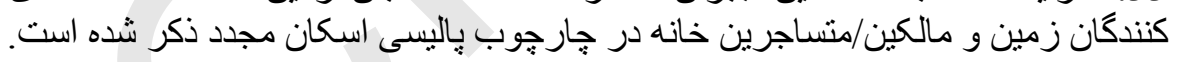

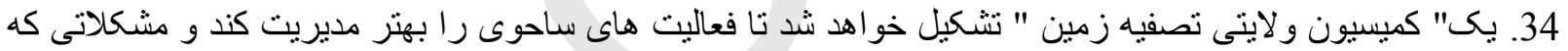

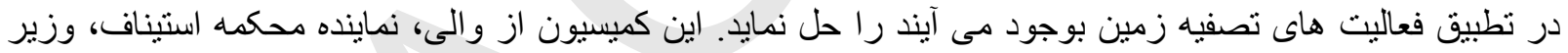

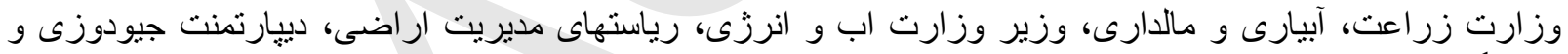

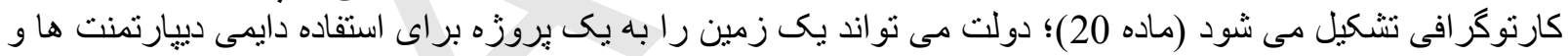

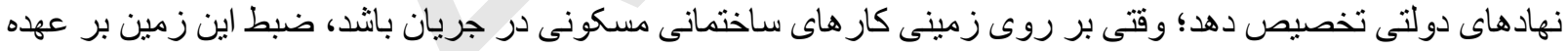

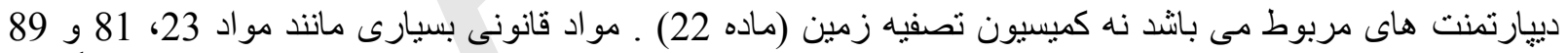

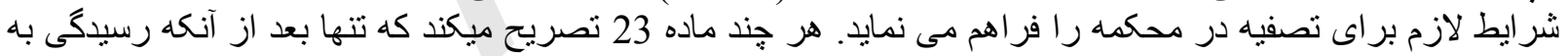

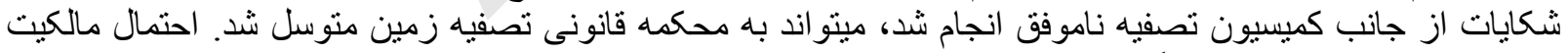

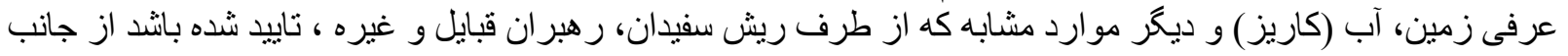

ماده 25 به رسميت شناخته شده است.

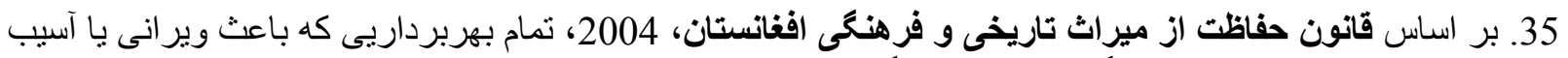

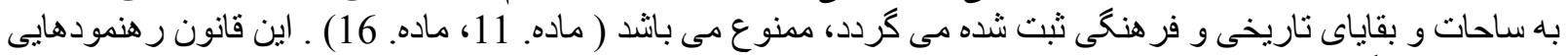

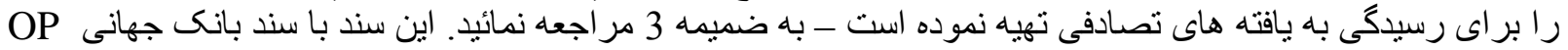

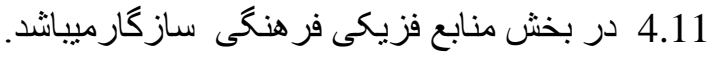

3. جهارجوب مديريت محيط زيستى و اجتماعى (ESMF) 


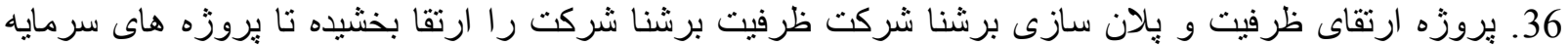

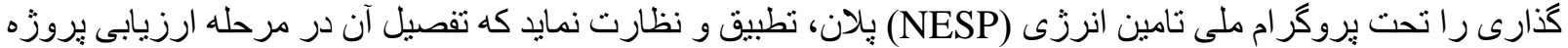

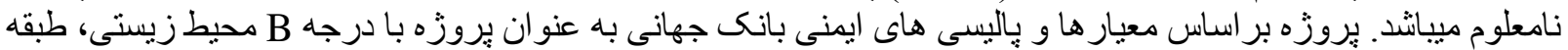

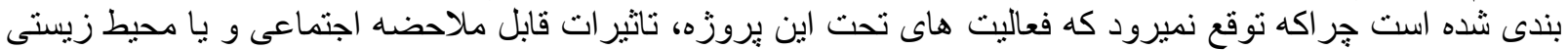

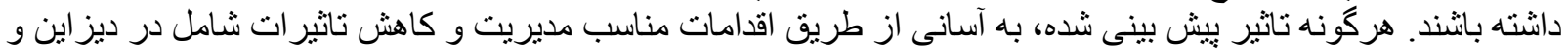

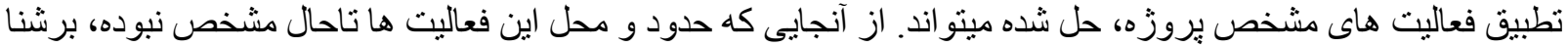

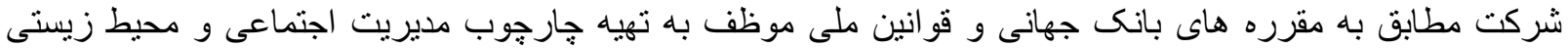

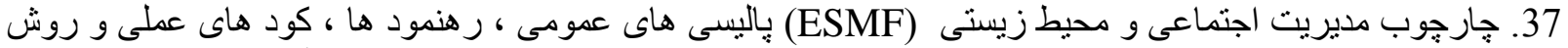

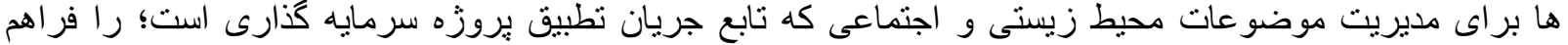

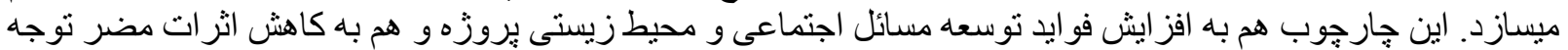

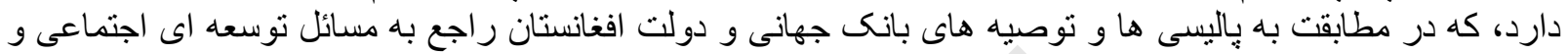
محيط زيستى , ميباشند.

38. جارجوب مديريت اجتماعى و محيط زيسنى براى تشخيص اوليه تاثئير ات مضر بالقوه نهيه شده و توصيه هاى بورد

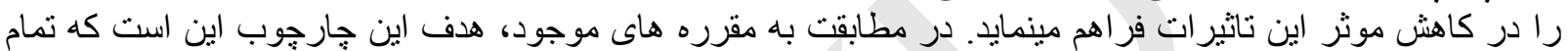

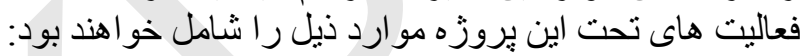

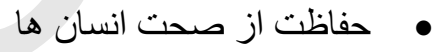

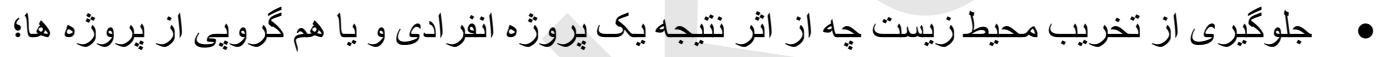

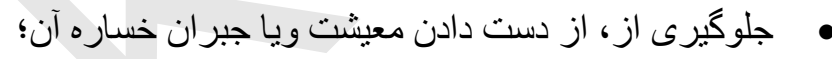

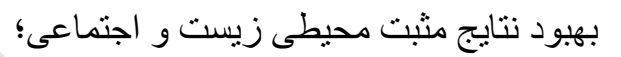

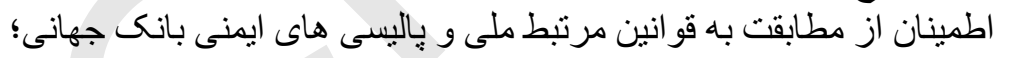

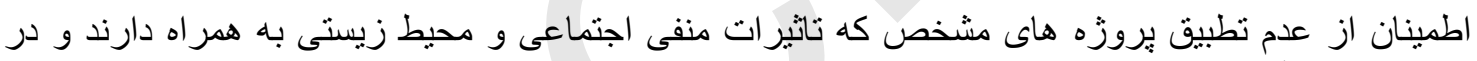

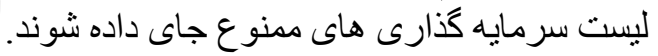

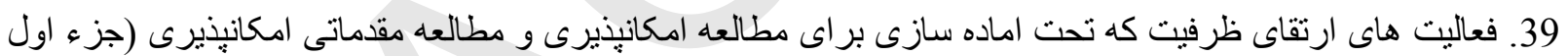

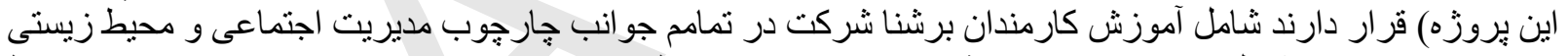

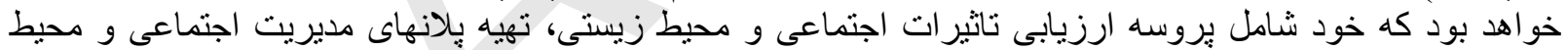

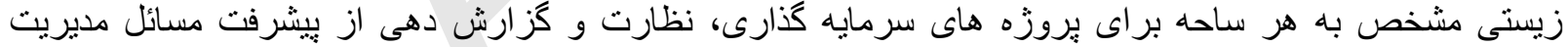

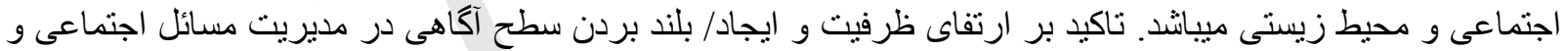

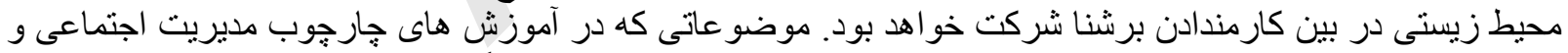

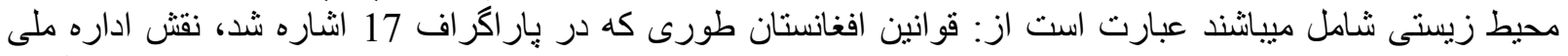

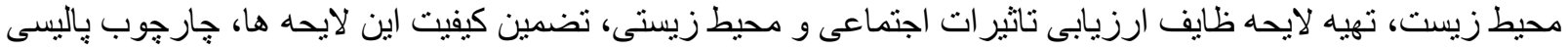

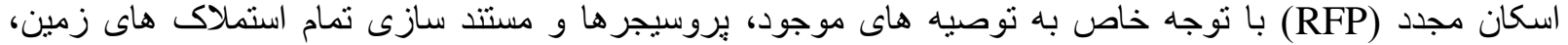

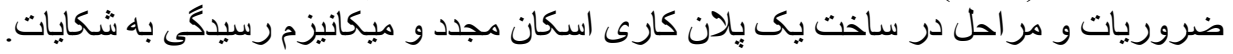

40. اين بروكر ام ارتقاى ظرفيت، رهنمودهاى محيط زيستى، صحت و ايمنى را به كار مندان برشنا شركت معرفى ميكند. (http://www.ifc.org/wps/wcm/connect/topics ext content/ifc external corporate site/ifc+sustainability lour+approach/risk+management/ehsguidelines )

و رهنماى محيط زيستى، صحت و ايمنى در انتقال و توزيع انرزى برق (ضميمه نمبر 15 را مشاهده كنيد) http://www.ifc.org/wps/wcm/connect/820ba70041685e578e6caf9e78015671/2007++Electric+Power+Transmission+and+Distribution.pdf?MOD=AJPERES

اين رهنمودها استندردهايى را كه توسط برشنا شركت در تهيه و تطبيق يروزه هاى برق بايد اعمال كردد، توضيح ميدهد. 
41. اندازه مركز آموزشى كه تحت جزء دوم بِروزه تمويل ميشود، در جريان ديز اين بروزه تثبيت خوا هد شد.

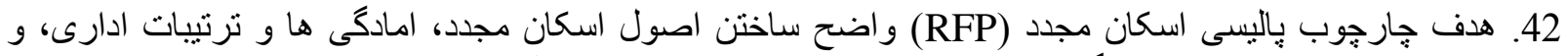

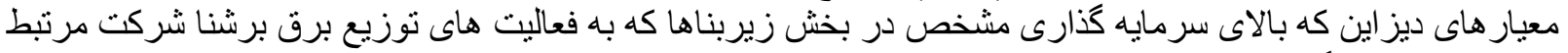

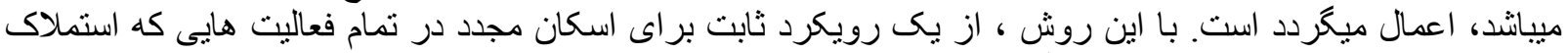

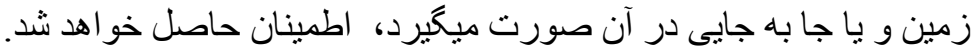

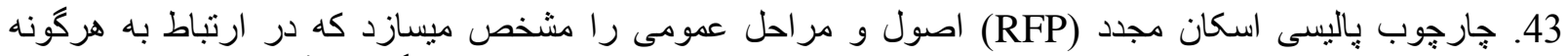

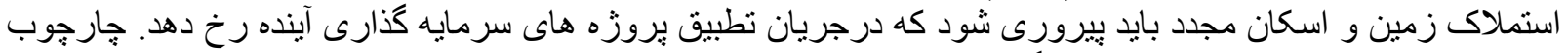

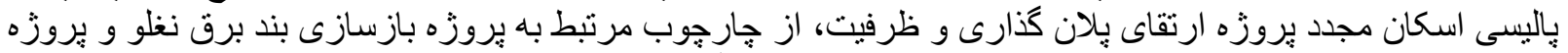

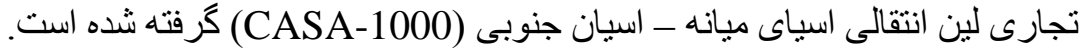

2.32 جهانى در افغانستان تمويل كرديده آندا:

44. تطبيق جارجوب در ديكر بروزه های كه از طريق بانك جهانى در كثور تمويل ميكرددبررسى گرديده و دروس

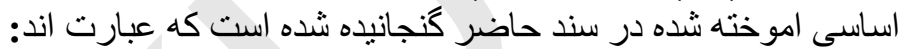

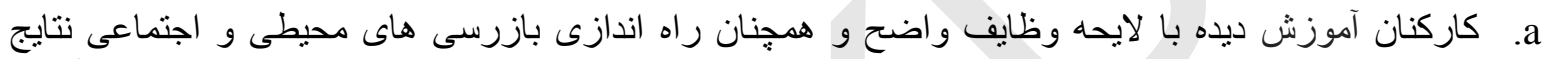

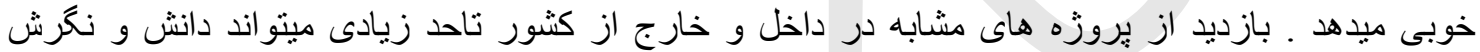

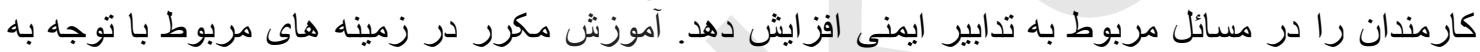
تعويض كاركنان مهم است.

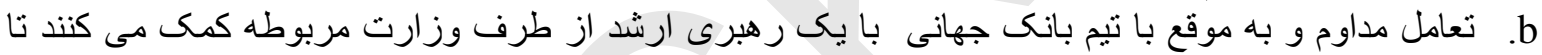

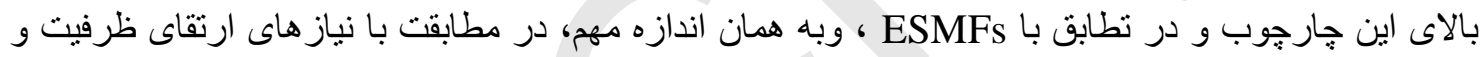

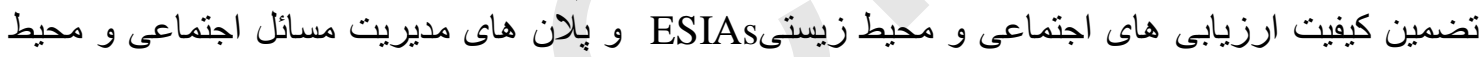

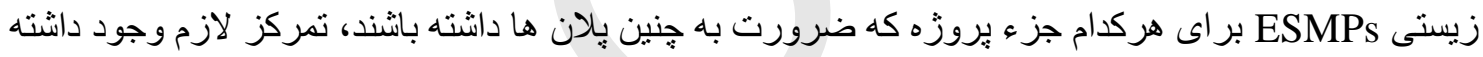
باشد. زبنى

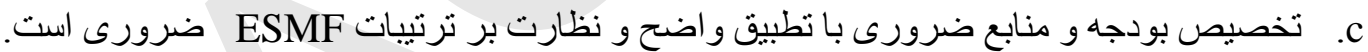

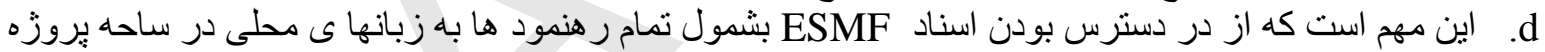
اطمينان حاصل نماييم.

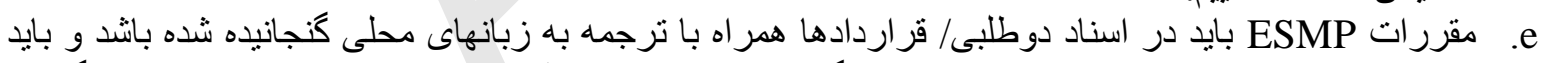

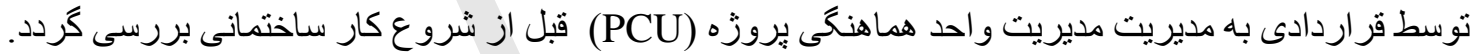

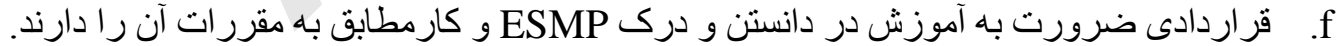

3.3

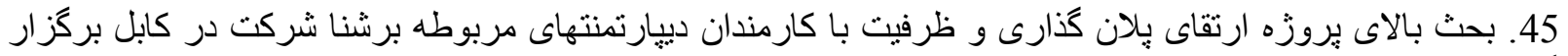

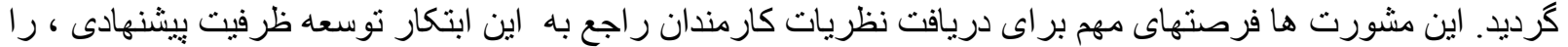

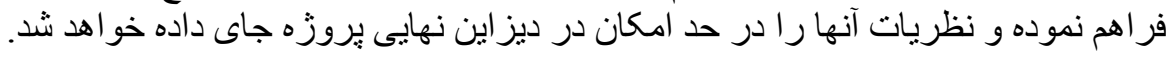

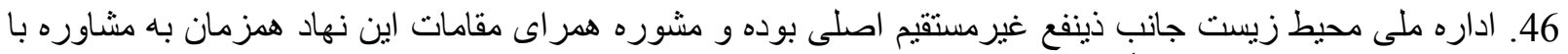

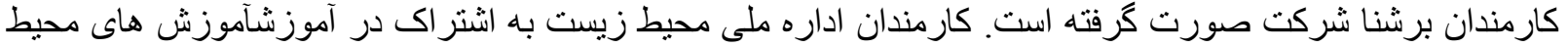

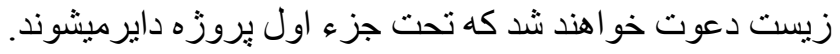

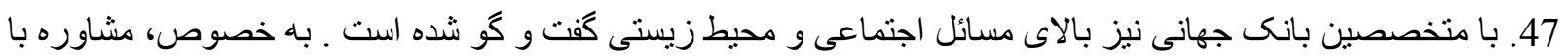

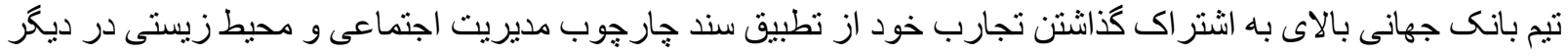




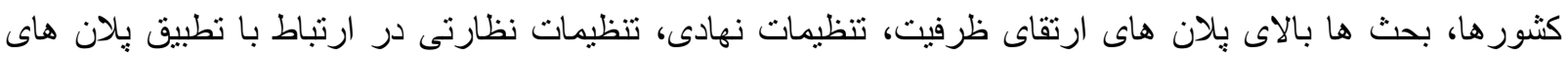

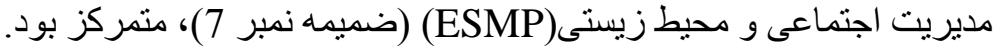

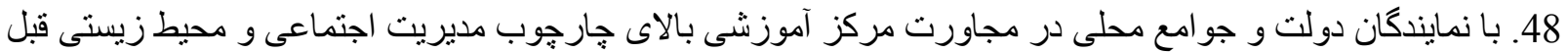

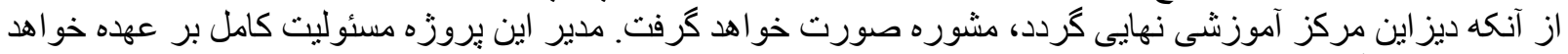

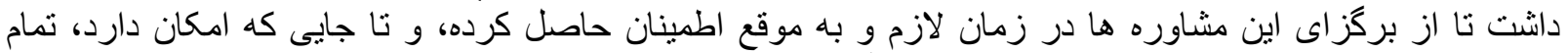

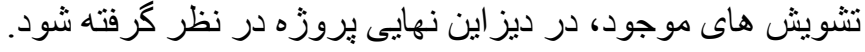

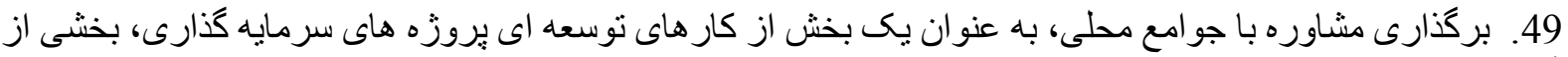

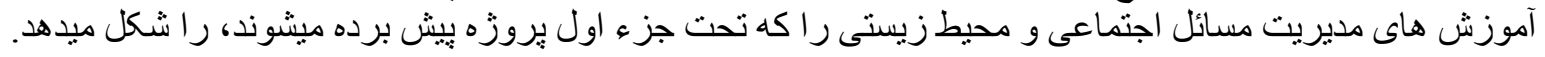

4.3 ترتيبات ادارى: شرايط ، بروسه ها و مسئوليت براى بررسى مسائل ايمنى و كاهش تاثيرات

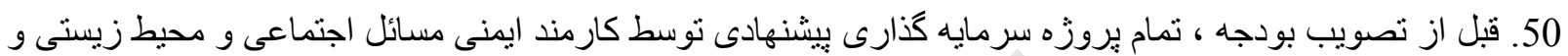

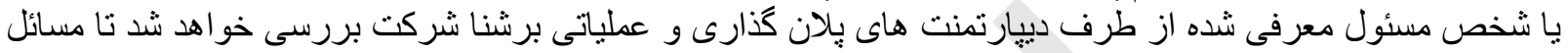

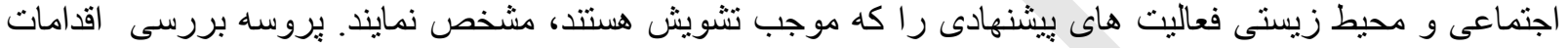

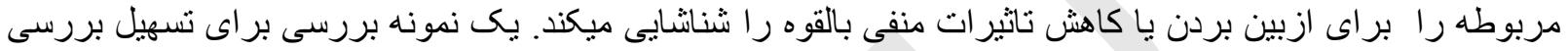

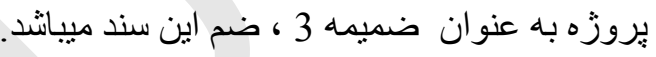

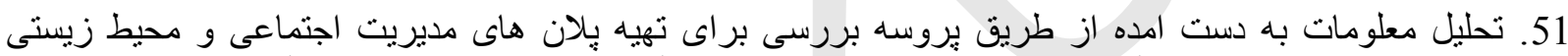

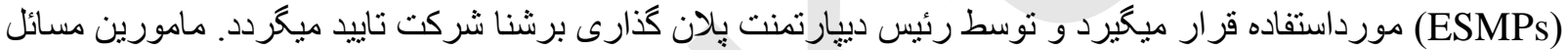

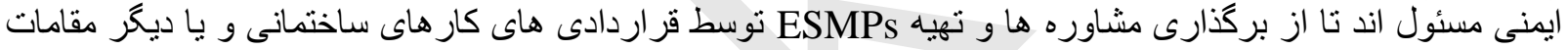

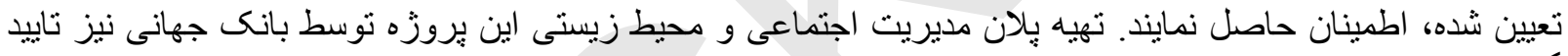
كردد.

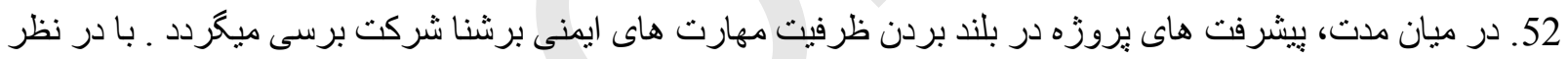

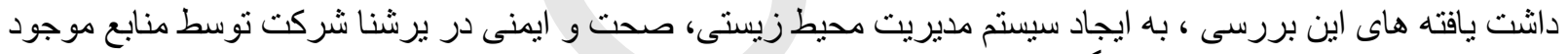

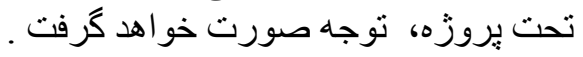

53. رئيس ارشد عملياتى (COO) برشنا شركت مسئوليت كامل خو اهد داشت تا از ر رعايت موثر با شر ايط هاى مندرج

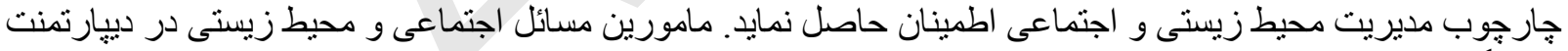

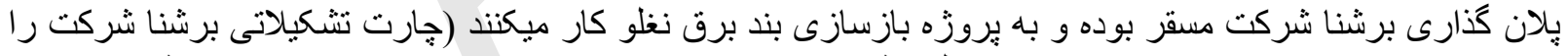

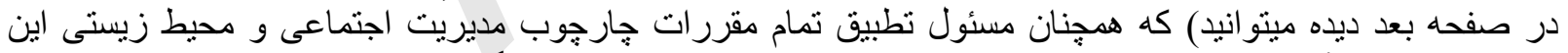

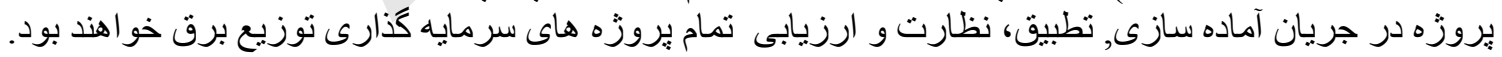




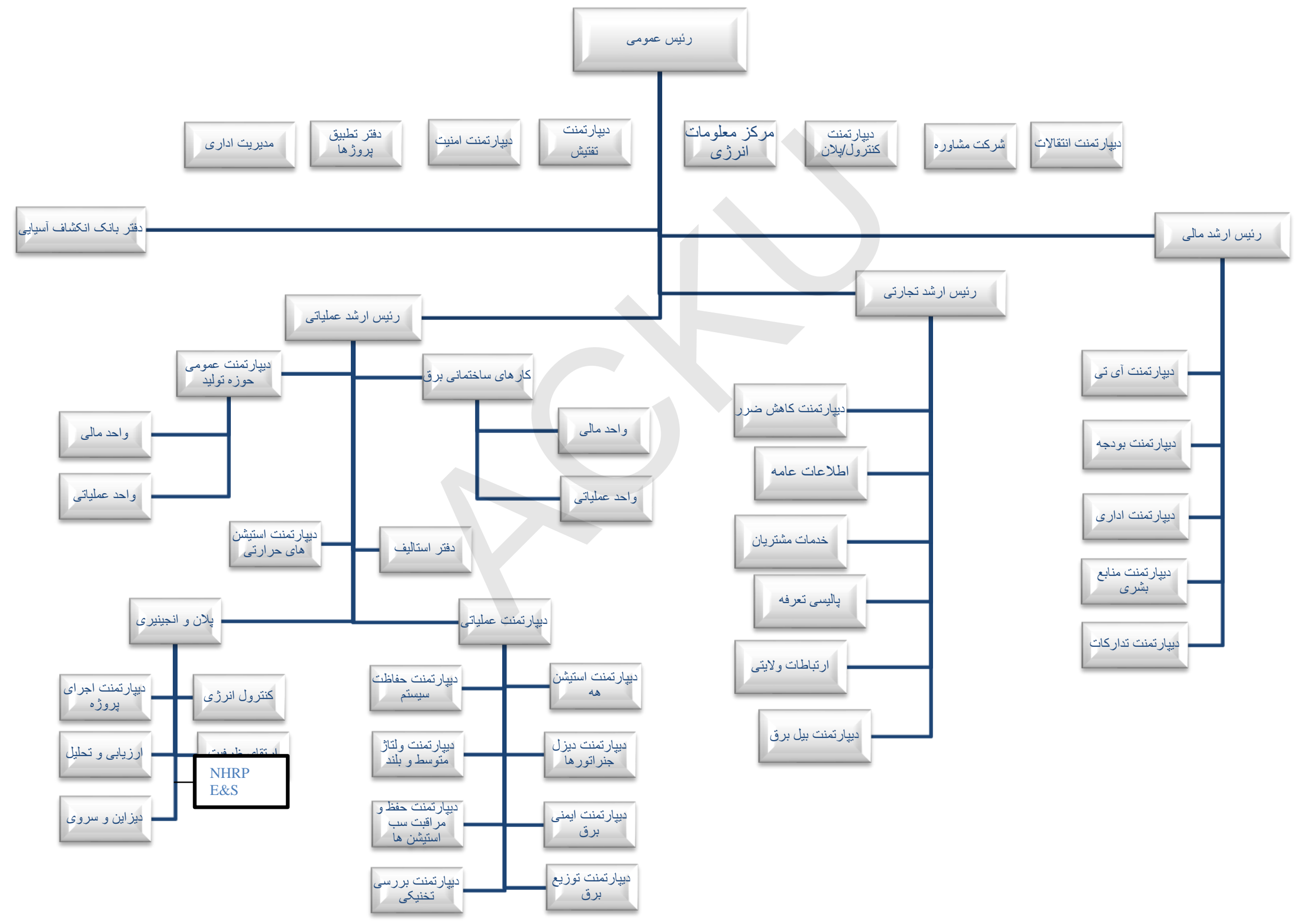




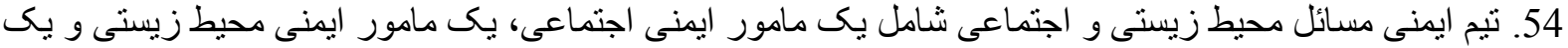

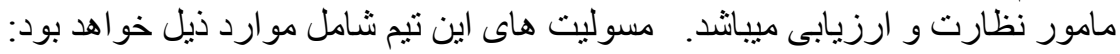

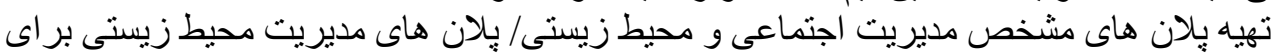
a

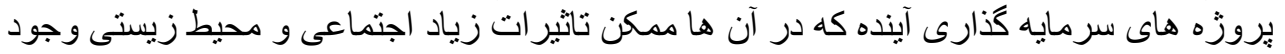
داشته باثند.

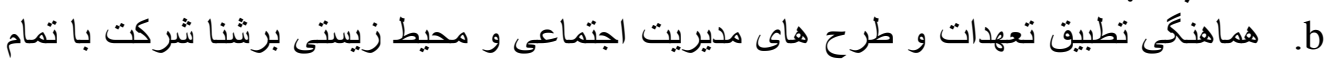

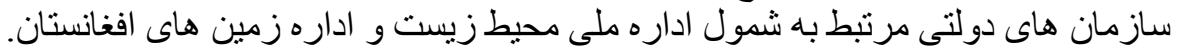

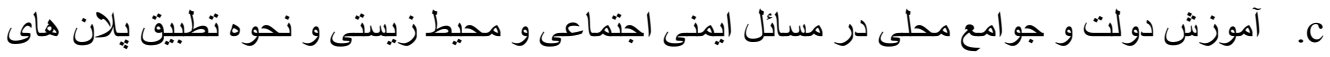

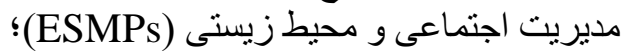

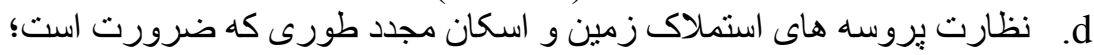

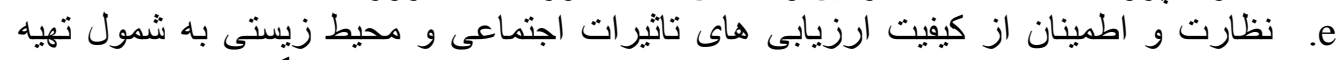

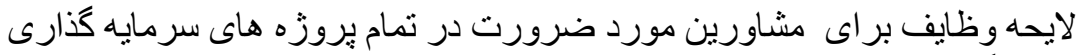

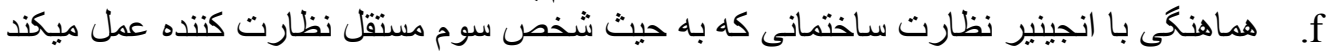

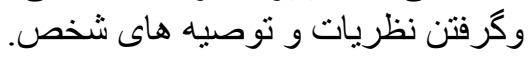

55. مامورين ايمنى اجنماعى و محيط زيستى آموزش هايى دريافت خواهند كرد كه آنها را قادر به بيشبرد مسئوليت

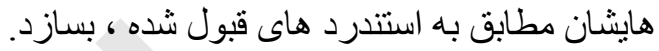



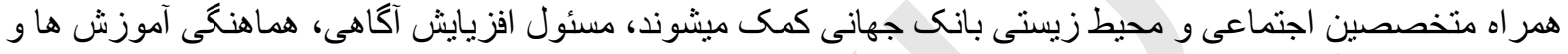

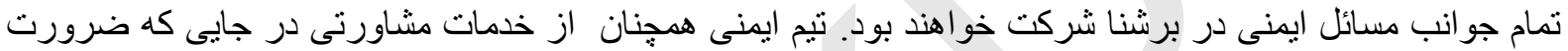
باثشد استفاده خو اهد كرد.

57. رئيس ارشد عملياتى (COO) برشنا شركت اطمينان حاصل خو اهد كرد كه طرز كار هاى برشنا شركت درسطح

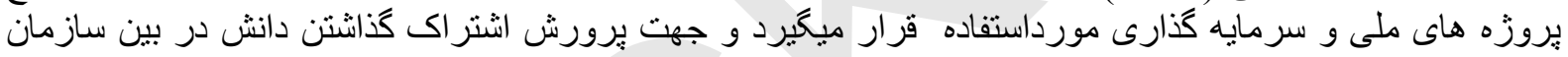

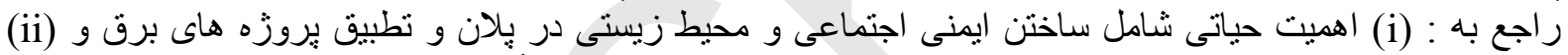

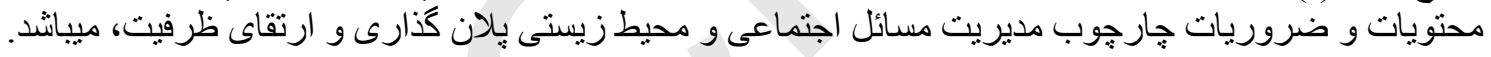

\section{3}

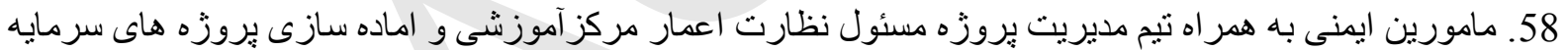

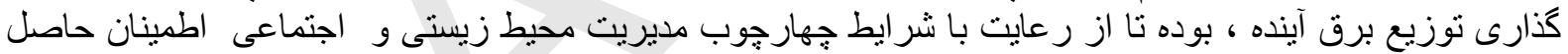

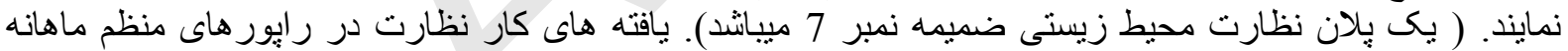

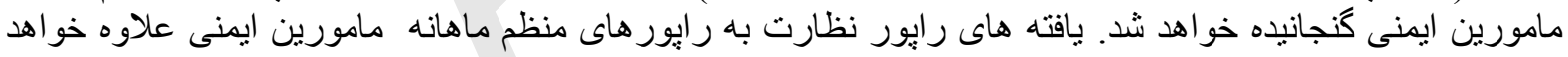

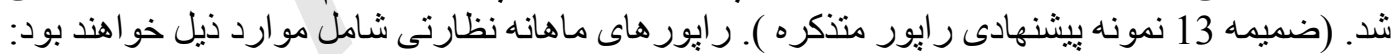

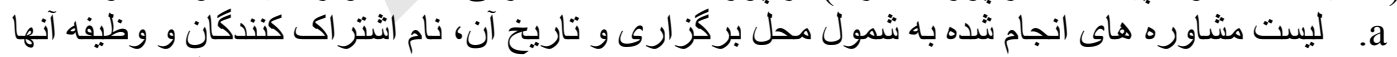

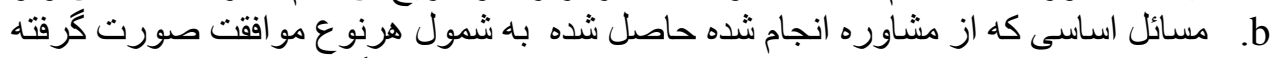

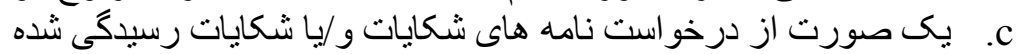

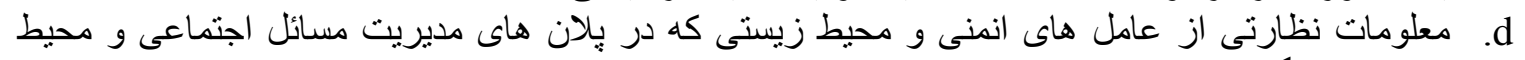
زيستى ذكر كرديده

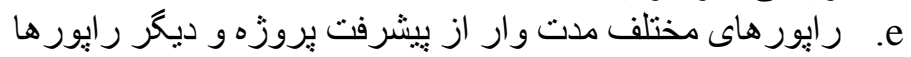
f . ترينينگ هائ

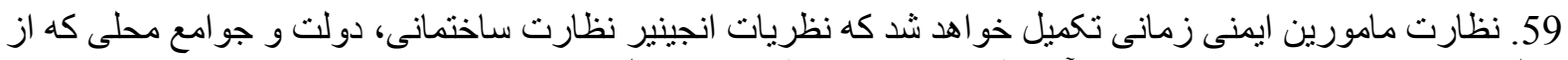

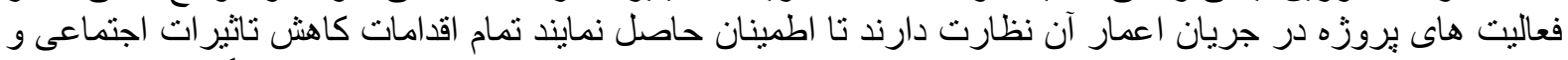

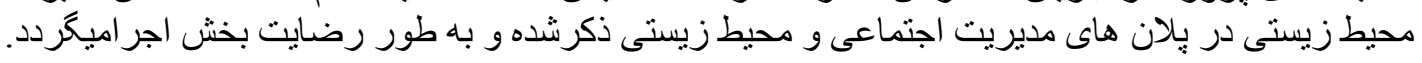

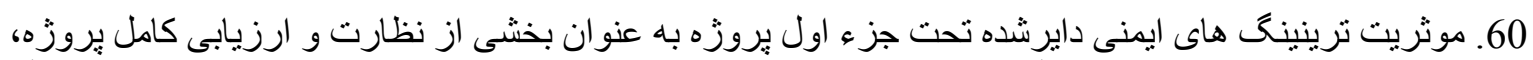

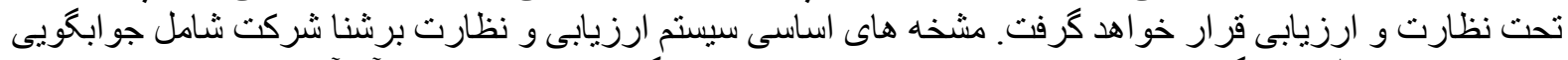

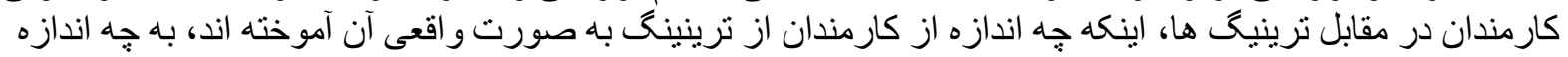

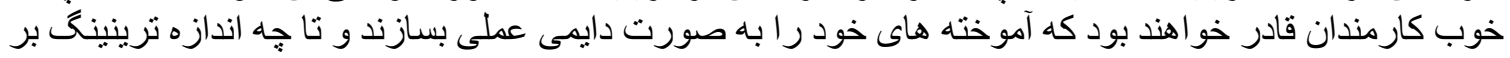


كيفيت كارى برشنا شركت ناثير كذاشته است ، خواهد بود.

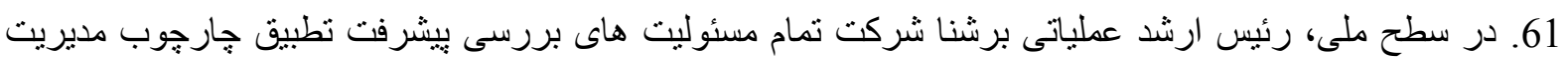

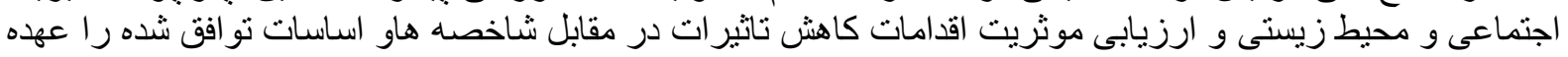

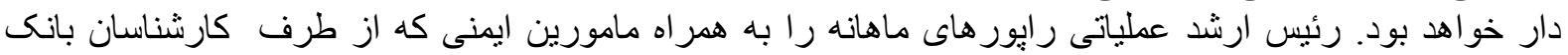

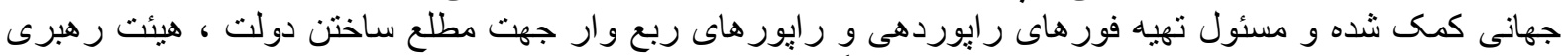

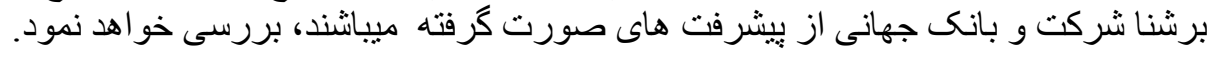

\section{3}

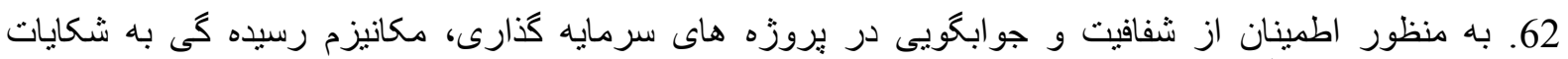

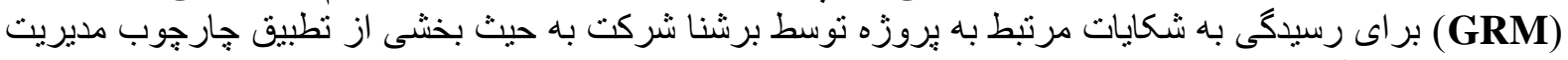

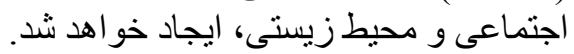

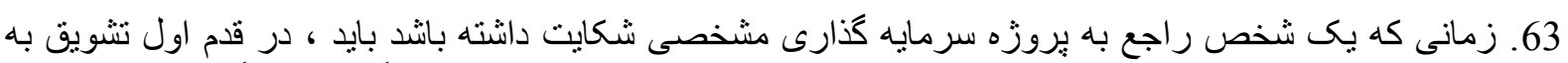

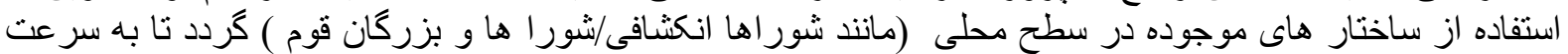

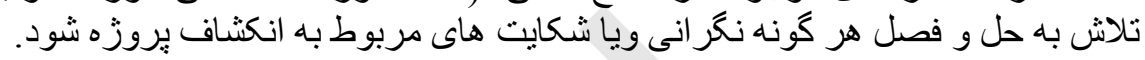

\section{ميكاتيزيم رسيدى بـ شكايات}

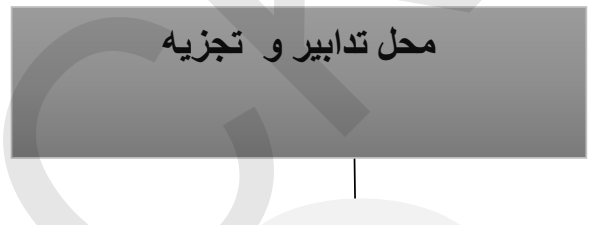

حل كرديد

بايان

اكر نه

كميته ميكانيزيم رسيدگي به شكايات

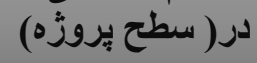

در 10روز

بايان

| اكر نه |

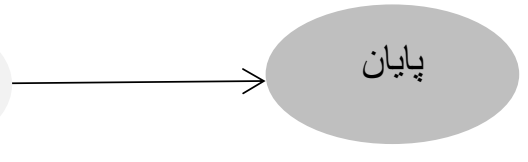

مديريت برشنا شركت / رئيس عملياتى

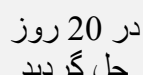

يايان

| اكر نه |

اكر حل نكر ديد ، ممكن مردم متضرر نظر به قو انين افغانستان بخاطر حق خود به محكمه مر اجعه كنند 


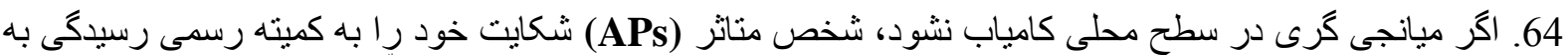

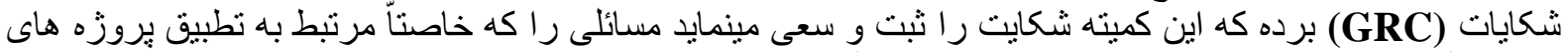

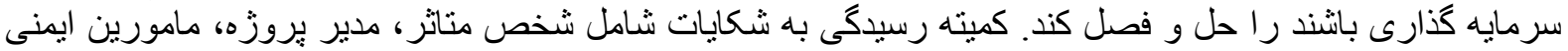

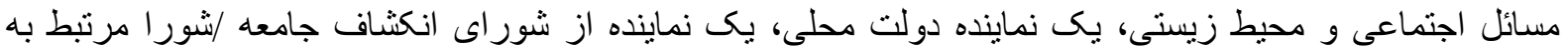

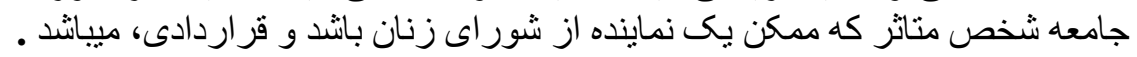

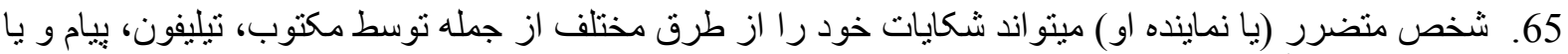

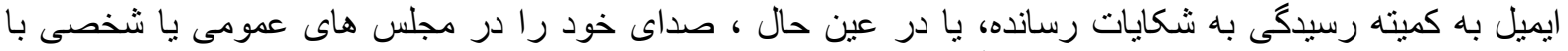

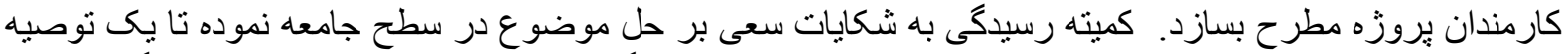

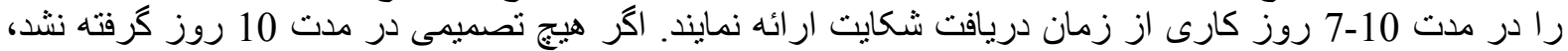

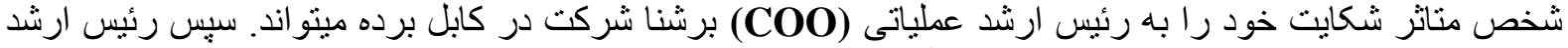

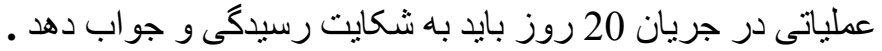

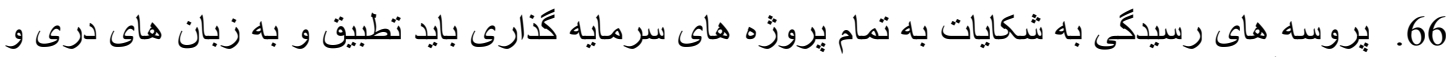

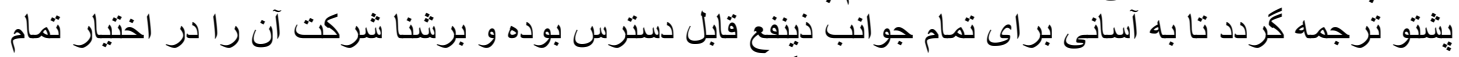

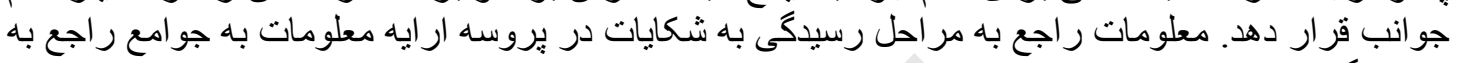

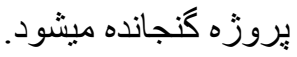

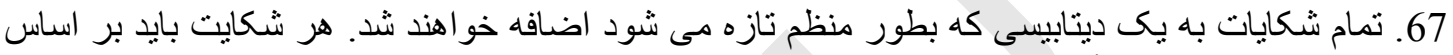

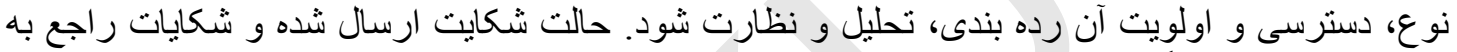

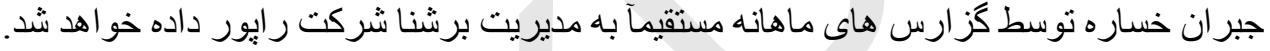

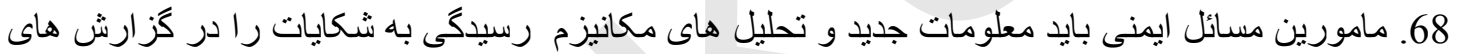

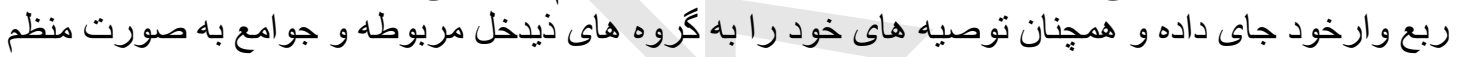
ار ائه نمايند.

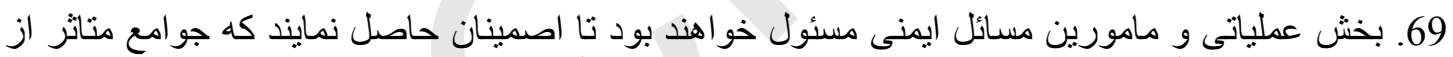

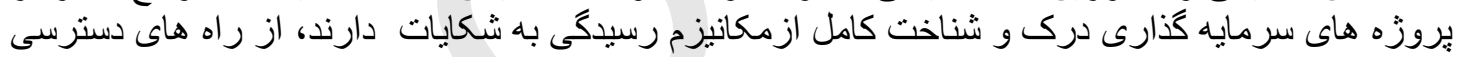

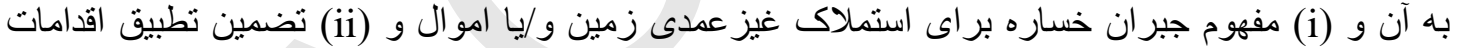
كاهش تاثير ات اجتماعى و محيط زيستى مطابق يلان ، آناهي دارئ دارند.

7.3 ترينينگ هاى عمده و مهم مسائل اجتماعى و محيط زيستى تحت جزء اول بِروزْه

\begin{tabular}{|c|c|c|}
\hline \multicolumn{3}{|c|}{ جزء اول: ترينينغ راجع به مطالعه امكانيذيرى و مطالعه مقدماتيى امكانيذيرى } \\
\hline عناصر اسنسى & وضوعات اجتماعى و محيط زيستى انتخاب شده & \\
\hline 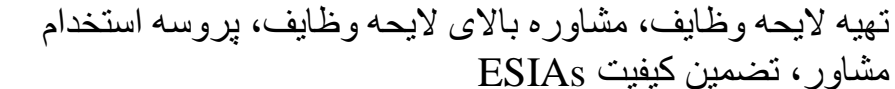 & $\begin{array}{r}\text { ارزيابى تاثيرات اجتماعى و محيط زيستى } \\
\text { (ESIAs) }\end{array}$ & \\
\hline 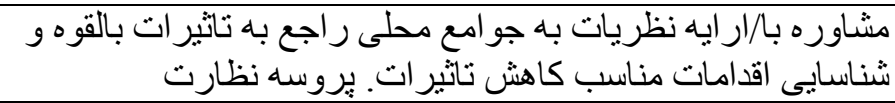 & 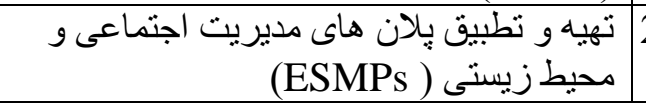 & \\
\hline 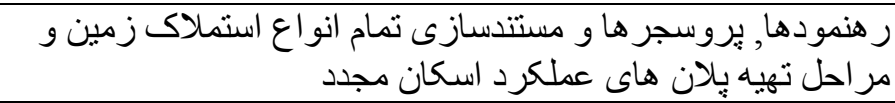 & 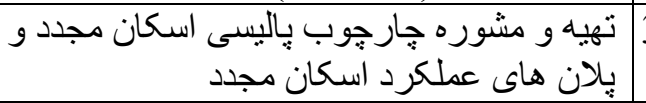 & 3 \\
\hline 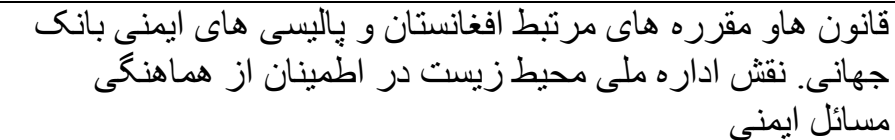 & ياليسى و مقرره محيط زيست & 4 \\
\hline 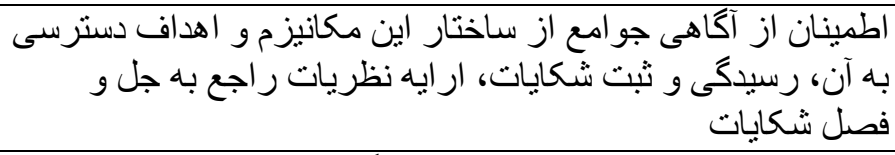 & رسيدكى به شكايات & 5 \\
\hline 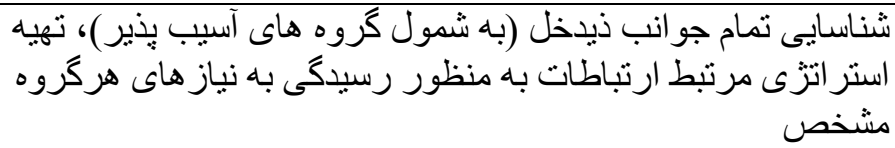 & 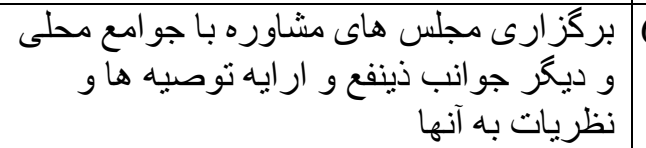 & \\
\hline
\end{tabular}


8.3 بودجه تخمينى براى رعايت ايمنى محيط زيستى و اجتماعى1

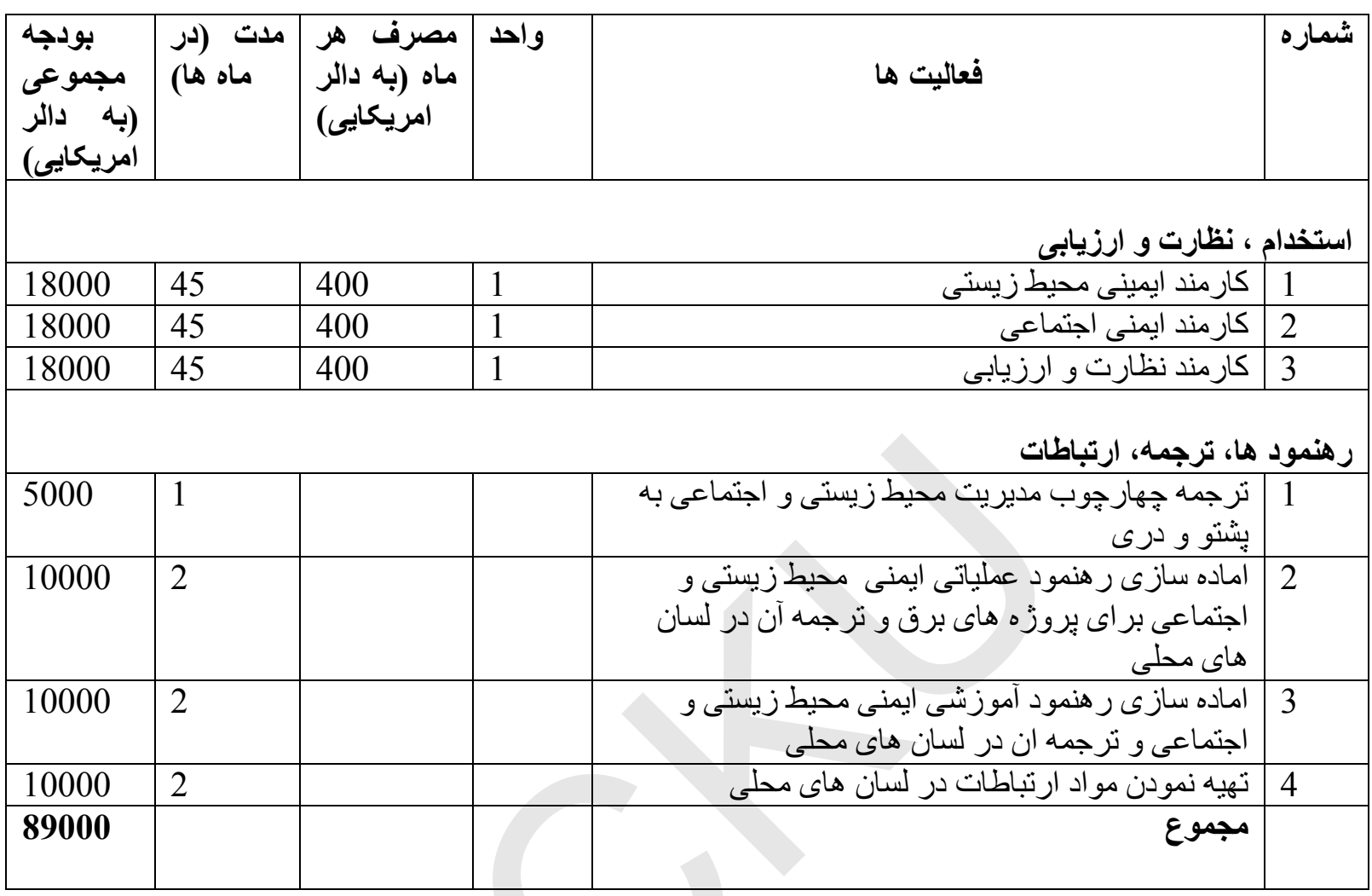

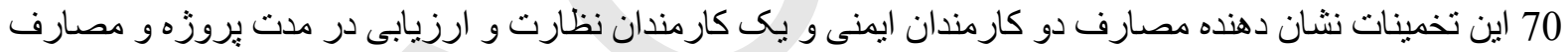

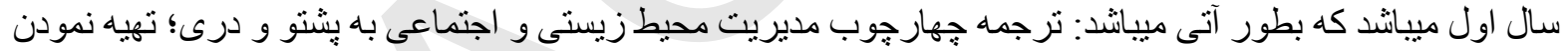

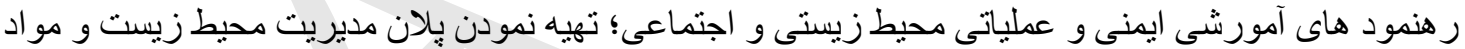

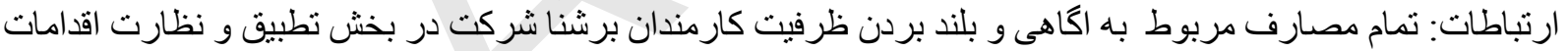
كاهش شامل جز 1 ميبانشند.

9.3 نشر معلومات

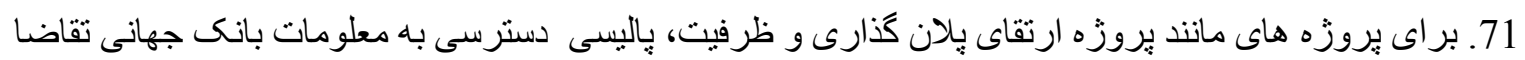

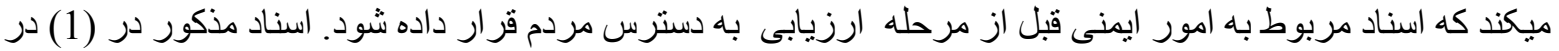

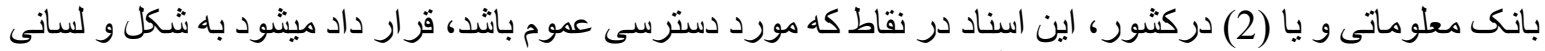

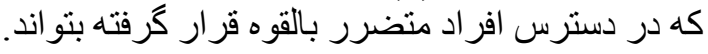

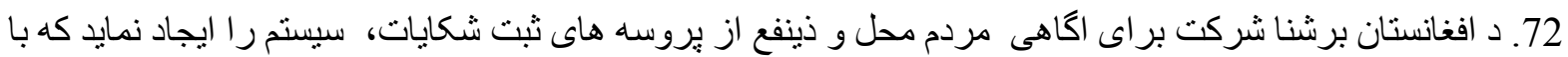

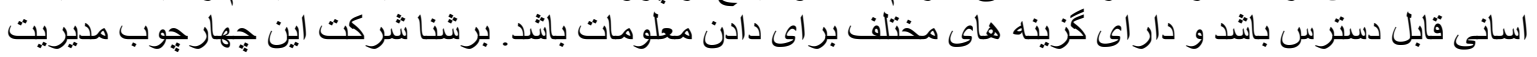

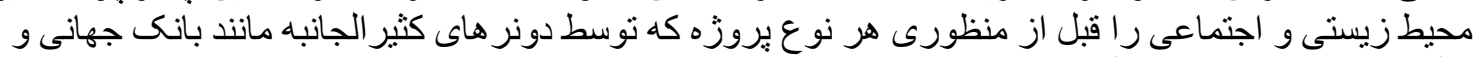

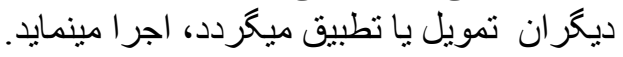

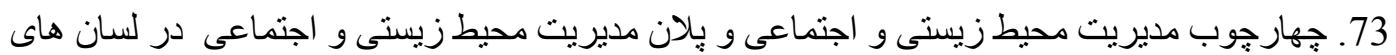

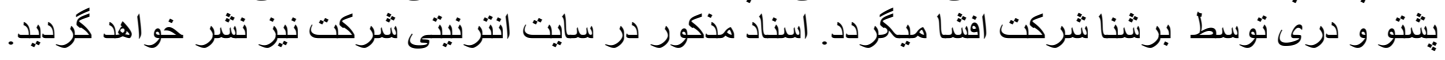

